\title{
Fine aerosol bulk composition measured on WP-3D research aircraft in vicinity of the Northeastern United States - results from NEAQS
}

\author{
R. E. Peltier ${ }^{1}$, A. P. Sullivan ${ }^{1, *}$, R. J. Weber ${ }^{1}$, C. A. Brock ${ }^{2}$, A. G. Wollny ${ }^{2,3}$, J. S. Holloway ${ }^{2,3}$, J. A. de Gouw ${ }^{2,3}$, and \\ C. Warneke ${ }^{2,3}$ \\ ${ }^{1}$ School of Earth and Atmospheric Science, Georgia Institute of Technology, Atlanta, GA, USA \\ ${ }^{2}$ National Oceanic and Atmospheric Administration, Earth Systems Research Laboratory, Boulder, CO, USA \\ ${ }^{3}$ Cooperative Institute for Research in Environmental Research, University of Colorado, Boulder, CO, USA \\ " now at: Department of Atmospheric Science, Colorado State University, Fort Collins, CO, USA
}

Received: 25 January 2007 - Published in Atmos. Chem. Phys. Discuss.: 27 February 2007

Revised: 5 June 2007 - Accepted: 11 June 2007 - Published: 25 June 2007

\begin{abstract}
During the New England Air Quality Study (NEAQS) in the summer of 2004, airborne measurements were made of the major inorganic ions and the water-soluble organic carbon (WSOC) of the submicron $\left(\mathrm{PM}_{1.0}\right)$ aerosol. These and ancillary data are used to describe the overall aerosol chemical characteristics encountered during the study. Fine particle mass was estimated from particle volume and a calculated density based on measured particle composition. Fine particle organic matter (OM) was estimated from WSOC and a mass balance analysis. The aerosol over the northeastern United States (U.S.) and Canada was predominantly sulfate and associated ammonium, and organic components, although in unique plumes additional ionic components were also periodically above detection limits. In power generation regions, and especially in the Ohio River Valley region, the aerosol tended to be predominantly sul-

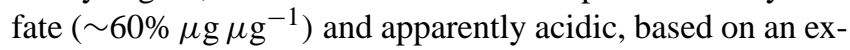
cess of measured anions compared to cations. In all other regions where sulfate concentrations were lower and a smaller fraction of overall mass, the cations and anions were balanced suggesting a more neutral aerosol. In contrast, the WSOC and estimated OM were more spatially uniform and the fraction of OM relative to PM mass was largely influenced by sources of sulfate. The study median OM mass fraction was $40 \%$. Throughout the study region, sulfate and organic aerosol mass were highest near the surface and decreased rapidly with increasing altitude. The relative fraction of organic mass to sulfate was similar throughout all altitudes within the boundary layer (altitude less than $2.5 \mathrm{~km}$ ), but was significantly higher at altitude layers in the free troposphere (above $2.5 \mathrm{~km}$ ). A number of distinct biomass burn-
\end{abstract}

Correspondence to: R. E. Peltier

(rpeltier@eas.gatech.edu) ing plumes from fires in Alaska and the Yukon were periodically intercepted, mostly at altitudes between 3 and $4 \mathrm{~km}$. These plumes were associated with highest aerosol concentrations of the study and were largely comprised of organic aerosol components $(\sim 60 \%)$.

\section{Introduction}

Atmospheric aerosols are known to be detrimental to human health (Dockery et al., 1993) and play a role in climate forcing through both a direct and indirect influence on the planetary radiation balance (IPCC, 2007). On average, sulfate is currently one of the most abundant aerosol species (by mass) observed in the atmosphere (Heintzenberg, 1989), and its thermodynamic and physical properties have been widely documented. Ammonium and nitrate are also common inorganic components of ambient particles. Inorganic compounds, such as sodium, chloride, potassium, calcium, and magnesium can also significantly contribute to particle mass in regions impacted by sea-spray and mineral dust. Carbonaceous material is another abundant aerosol component, however it is not well characterized due to its complex chemical nature (Eatough et al., 1993; Rogge et al., 1993; Zappoli et al., 1999). New insights into the sources and processing of atmospheric aerosols can be gained by large intensive field campaigns in which multiple gas-phase and aerosol measurements, together with meteorological analysis tools and emission inventories, can be used to identify specific characteristics, sources, and processes involving the aerosol and their chemical precursors.

It has long been established that the northeastern US and Canada are often affected by anthropogenic emissions from

Published by Copernicus Publications on behalf of the European Geosciences Union. 
the midwestern U.S. (Kelleher and Feder, 1978), and that this transport can extend from the continent for $500 \mathrm{~km}$ or more (Beattie and Whelpdale, 1989). Previous research programs, such as NARE (Fehsenfeld et al., 1996), TARFOX (Russell et al., 1999), and NEAQS2002 (Bates et al., 2005), have investigated the characteristics and sources of aerosol particles and gases in this region of the U.S.

The International Consortium for Atmospheric Research on Transport and Transformation (ICARTT), a multinational and multiplatform research initiative, recently studied the transport of pollutants and atmospheric chemistry of the Northeastern United States and Canada (Fehsenfeld et al., 2006). The National Oceanic and Atmospheric Administration's (NOAA) WP-3D research aircraft participated in these experiments. Based in Portsmouth, NH $(43.08 \mathrm{~N}$, $-70.82 \mathrm{~W}$ ), research flights were conducted over regions that included the Canadian Maritime provinces, northern Quebec, New England, the Ohio River Valley, and western edge of the North Atlantic. Measurements were made during the period of 5 July to 15 August, 2004.

This paper identifies the main chemical components, their sources and the resulting spatial distribution of the bulk $\mathrm{PM}_{1.0}$ aerosol (aerodynamic diameters less than $1.0 \mu \mathrm{m}$ ) that were sampled throughout the summer field campaign. Other papers focus on specific plumes to investigate the evolution of fine particles from anthropogenic emissions along the urban corridor from Washington D.C. to Boston MA (Sullivan et al., 2006; Brock et al., 2007 ${ }^{1}$ ).

\section{Experimental methods}

Fine particle bulk chemical composition was measured online from the NOAA WP-3D aircraft with two automated systems, each involving a Particle-Into-Liquid Sampler (PILS). One PILS was coupled to two Metrohm ${ }^{\circledR}$ ion chromatographs (Model 761, Houston, TX), while the second was coupled to a Sievers total organic carbon analyzer (GE Water Systems, Model 800T, Boulder, CO). The first instrument package is referred to as PILS-IC (ion chromatography), and the second as PILS-WSOC (water soluble organic carbon). PILS-IC has been described in previous research (Ma et al., 2003; Orsini et al., 2003; Weber et al., 2001). The PILS-WSOC instrument is described in detail by Sullivan et al. (2006). Both instruments sampled ambient aerosol from a shared low-turbulence inlet (LTI) (Wilson et al., 2004), each sampling at $15.0 \mathrm{l} / \mathrm{min}$. Upstream of the instruments, a nonrotating micro-orifice impactor (Marple et al., 1991) with $1.0 \mu \mathrm{m}$ cut size (at 1 atmosphere) removed particles with aerodynamic diameters greater than $1.0 \mu \mathrm{m}$ aerodynamic di-

\footnotetext{
${ }^{1}$ Brock, C. A., Wollny, A. G., de Gouw, J. A., Warneke, C., Fehsenfeld, F. C., Peltier, R. E. Sullivan, A. P, and Weber, R. J.: Secondary Aerosol Formation in Pollution Plumes Transported from the East Coast of the United States, in preparation, 2007.
}

ameter at relative humidity that may have been significantly lower than ambient due to sample heating within the aircraft.

\section{$2.1 \quad$ PILS-IC}

The PILS-IC was operated using a chromatographic separation of $2.45 \mathrm{~min}$ for both the cations (ammonium, sodium, calcium, potassium, magnesium) and anions (chloride, sulfate, and nitrate). A "Cation 1-2" column and "Anion A Supp $5(100 \mathrm{~mm})$ " column (Metrohm-Peak, Houston, TX) was operated at an eluent flow rate of $1.5 \mathrm{ml} \mathrm{min}^{-1}$, and $1.05 \mathrm{ml} \mathrm{min}^{-1}$, respectively. Eluents used during this campaign were $11 \mathrm{mM} \mathrm{Na}_{2} \mathrm{CO}_{3}$ (sodium carbonate), $6 \mathrm{mMNaHCO}_{3}$ (sodium bicarbonate) for anion exchange, and $8.5 \mathrm{mML}$-tartaric acid, $4.1 \mathrm{mM}$ dipicolinic acid for cation exchange. With the liquid flow rates used in this campaign, limit of detection ranged from $0.2 \mu \mathrm{g} \mathrm{m}^{-3}$ for cation species (except potassium ion, which was $0.5 \mu \mathrm{g} \mathrm{m}^{-3}$ ) to $0.02-0.04 \mu \mathrm{g} \mathrm{m}^{-3}$ for anions. The PILS impactor was continuously washed with a transport flow of $0.19 \mathrm{ml} \mathrm{min}^{-1}$ of ultrapure deionized water spiked with lithium fluoride as an internal standard. Liquid sample from the PILS was split between the anion and cation ICs. Each flow was continuously drawn via syringe pumps into a $150 \mu \mathrm{l}$ sample loop at a rate of $100 \mu 1 \mathrm{~min}^{-1}$, resulting in a $90 \mathrm{~s}$ sample integration time. The resulting measurement interval was $2.45 \mathrm{~min}$, with each sample representing a 90 -s collection time.

To eliminate interferences from gases, sample air passed through a carbon monolith denuder and a set of etched glass honeycomb denuders prior to entering the PILS-IC. One etched glass denuder was coated with citric acid (for removal of gases such as $\mathrm{NH}_{3}$ (ammonia)), and the second was coated with sodium carbonate (for removal of gases such as $\mathrm{HNO}_{3}$ (nitric acid), $\mathrm{SO}_{2}$ (sulfur dioxide), and $\mathrm{HCl}$ (hydrochloric acid)). Before each flight, a valve diverted the sampled aerosol through a HEPA filter for an assessment of denuder function, as well as a quantification of backgrounds. Sulfate was the only ionic compound measured with detectable background interference, which was generally constant at $0.015 \mu \mathrm{g} \mathrm{l}^{-1}$ (equivalent to ambient aerosol concentration of $10 \mathrm{ng} \mathrm{m}^{-3}$ ). The sulfate background was subtracted from the dataset.

The ion chromatographs were calibrated using known dilutions of NIST-traceable liquid anion and cation stock standards. Linear calibration curves forced through zero were determined from five different concentrations of anions and cations that spanned the range of ionic concentrations typical for aerosol liquid samples collected from the PILS. The cation IC was calibrated before the mission began, and was re-calibrated near the middle and at the end of the mission. Sensitivity changed by less than $5 \%$ over the 6 -week project. The anion column was calibrated before the mission; however, the column was replaced and calibrated on 29 July 2004 and the system was re-calibrated at the end of the mission (again, with no significant change in calibration constants). 


\subsection{PILS-WSOC}

A Particle-Into-Liquid Sampler coupled to a total organic carbon (TOC) analyzer (GE Water Systems, 800T, Boulder, $\mathrm{CO})$ was used to measure the water-soluble organic carbon (WSOC) component of fine particles. WSOC was measured with a PILS-WSOC that functions similar to a PILS-IC, however, in this case the PILS liquid sample is quantified for carbon mass. The PILS was operated so that the collected particles were mixed with a transport flow of ultrapure deionized water to produce a total liquid flow rate of $1.3 \mathrm{ml} \mathrm{min}^{-1}$. This sample liquid was pumped through a $0.5 \mu \mathrm{m}$ PEEK filter via two $2.5 \mathrm{ml}$ glass syringe pumps (Versa 3, Kloehn Inc.) operating in an alternating tandem mode to provide a smooth continuous flow. The TOC analyzed most of this flow by running at a sample flow rate of $1.2 \mathrm{ml} \mathrm{min}{ }^{-1}$. The instrument quantifies the carbon mass by converting carbon in the liquid sample to $\mathrm{CO}_{2}$ (carbon dioxide) through a combination of chemical and UV oxidation. The $\mathrm{CO}_{2}$ is then detected by conductivity. This instrument operated at a 3 -s measurement rate with a detection limit of approximately $0.1 \mu \mathrm{gC} \mathrm{m}^{-3}$ and estimated measurement uncertainty of $\pm 8 \%+0.3 \mu \mathrm{gC} \mathrm{m}^{-3}$ (Sullivan et al., 2006). Liquid concentrations (in parts per billion carbon, or ppbC) of WSOC ranged from $10 \mathrm{ppbC}$ to approximately $300 \mathrm{ppbC}$ for the flow rates employed and regions investigated during the airborne experiment.

Upstream to the PILS-WSOC, sample air is passed through an activated carbon parallel-plate denuder (Eatough et al., 1993) to remove organic vapors. Throughout all flights, a computer-activated valve was triggered every $3 \mathrm{~h}$ to direct the sample through a Teflon filter for quantifying the backgrounds by assessing any positive artifacts due to gas penetration through the denuders and absorption in PILS, and organic artifacts in the sample water. This background was assumed constant between consecutive background measurements and subtracted from the dataset. Although the TOC analyzer is factory calibrated, a series of oxalic acid standards were used to verify calibration stability. Calibrations were typically within $5 \%$ of the factory calibration.

Data were recorded continuously at 3-s integrals. In the following analysis, the data have been averaged to $1 \mathrm{~min}$, where the average would only be computed if at least $75 \%$ of possible data points were valid within the one-minute window. For a more detailed discussion on the PILS-WSOC, see Sullivan et al. (2006).

\subsection{Other instrumentation}

Additional supporting measurements were used throughout the analysis and include $1 \mathrm{~s}$ observations of sulfur dioxide $\left(\mathrm{SO}_{2}\right)$ and carbon monoxide (CO) (Holloway et al., 2000) and gaseous organic compounds measured by a proton transfer reaction-mass spectroscopy (PTR-MS) with an approximate sampling frequency of $18 \mathrm{~s}$ (de Gouw et al., 2003). $\mathrm{PM}_{1.0}$ volume, which is used extensively in the following

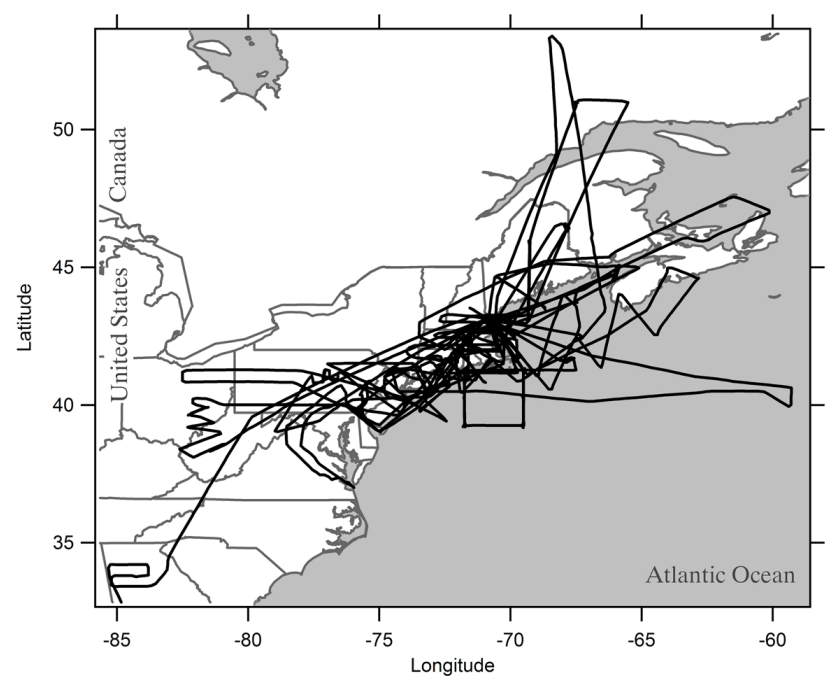

Fig. 1. Overview of all WP-3D flight tracks flown during the NEAQS experiment. The aircraft was based at Pease Airfield in Portsmouth, NH. 17 research flights were conducted and were typically 8-9 hours in duration.

analysis, was measured at $1 \mathrm{~s}$ resolution using a combination of three instruments: a battery of 5 condensation particle counters (CPC), a modified Lasair 1001 optical particle counter (OPC), and a white light optical particle counter (WLOPC) (Brock et al., 2004; Brock et al., 2003). Located in a pod under an aircraft wing, the CPC measured total concentrations in five cumulative particle size ranges $(0.004 \mu \mathrm{m}$ to $0.055 \mu \mathrm{m}$ ). The OPC measured concentrations in 64 size bins spanning the size range from $0.15 \mu \mathrm{m}$ to $0.95 \mu \mathrm{m}$ diameter. Sampled air was heated to $35^{\circ} \mathrm{C}$ for the $\mathrm{CPC}$, and was not heated in the case of the OPC. However, relative humidity was measured in the inlet of the OPC, and the data were corrected to $\mathrm{RH}$ of $40 \%$ using a fitted curve of hygroscopic diameter growth for mixed sulfate/organic particles as described by Santarpia et al. (2004). Lastly, the WLOPC was located inside the aircraft and measured size bins from $0.7 \mu \mathrm{m}$ to $8.0 \mu \mathrm{m}$. The data are processed by an inversion technique which determines a smooth and continuous size distribution that is consistent with the data and experimental response of the instruments, as well as with the instrument uncertainty. A more detailed description of volume measurement methodology, calibration, and uncertainty can be seen in Brock et al. (2007) $)^{1}$, Brock et al. $(2000,2002)$, and Wollny et al. $(2007)^{2}$. Ambient pressure and temperature were recorded while in flight and used to adjust all aerosol particle concentration data reported here to standard conditions $\left(20^{\circ} \mathrm{C}\right.$ and 1 atmosphere).

\footnotetext{
${ }^{2}$ Wollny, A. G., Brock, C. A. de Gouw, J. A., Warneke, C., Fehsenfeld, F. C., Peltier, R. E. Sullivan, A. P, and Weber, R. J.: Microphysical and chemical properties of particles in aged biomass burning plumes from forest fires in Alaska and Western Canada, in preparation, 2007.
} 


\section{Results}

Airborne measurements provide the opportunity to sample with a single set of instruments large geographic regions and a range of altitudes. A map, including aircraft flight paths during the deployment based out of Portsmouth, New Hampshire is shown in Fig. 1. During this experiment, a majority ( $\sim 69 \%)$ of observations took place at altitudes less than 2000 meters above sea level.

\subsection{Aerosol composition - main chemical components of $\mathrm{PM}_{1.0}$}

Table 1 summarizes the bulk aerosol composition measurements that were made from the NOAA WP-3D during the NEAQS field campaign. For the species measured, both below and above $2 \mathrm{~km}$ altitude, the two main components by mass were sulfate and WSOC. Sulfate was observed throughout the field campaign with a mean concentration of $3.86 \mu \mathrm{g} \mathrm{m}^{-3}$, although the range of observation spanned from the limit of detection (LOD, see Table 1) to $30.96 \mu \mathrm{g} \mathrm{m}^{-3}$. Ammonium ion was also commonly observed, with a mean concentration of $1.1 \mu \mathrm{g} \mathrm{m}^{-3}$ (range: LOD to $6.5 \mu \mathrm{g} \mathrm{m}^{-3}$ ) and was well correlated with sulfate $\left(r^{2}=0.74\right)$. Water-soluble organic carbon (WSOC) averaged $2.2 \mu \mathrm{g} \mathrm{C} \mathrm{m}^{-3}$, and ranged from the LOD to $25.6 \mu \mathrm{g} \mathrm{C} \mathrm{m}^{-3}$, with highest concentrations measured within biomass burning plumes.

The other measured ions were nearly always below the limit of detection, with the exception of periodic encounters with unique plumes. For example, at the detection limit of $0.04 \mu \mathrm{g} \mathrm{m}^{-3}$, nitrate ion was almost exclusively observed in biomass burning plumes and was often correlated with the ammonium ion. This finding was expected since nitrate is a known component of biomass burning smoke (Chow et al., 1994) and is unlikely to be observed at significant concentrations in fine particles during the summertime in the northeastern U.S. (Tolocka et al., 2001).

Compounds associated mainly with mineral dust, calcium $\left(\mathrm{Ca}^{2+}\right)$ and magnesium $\left(\mathrm{Mg}^{2+}\right)$, and sea-salt particle components, sodium $\left(\mathrm{Na}^{+}\right)$and chloride $\left(\mathrm{Cl}^{-}\right)$, were usually near or below the detection limits for the $\mathrm{PM}_{1.0}$ particles sampled in this mission. Potassium $\left(\mathrm{K}^{+}\right)$ion was typically below the $\mathrm{LOD}$, even during biomass burning plume sampling. This is significant because these plumes contained the highest concentrations of aerosol mass measured during the experiment and other studies have shown that $\mathrm{K}^{+}$is prevalent in fine particle biomass burning smoke, (Lee et al., 2003; Ma et al., 2003). Assuming $\Delta \mathrm{K}^{+}$concentration equals $0.25 \mu \mathrm{g} \mathrm{m}^{-3}$, (one-half the instrument LOD for $\mathrm{K}^{+}$, and background $\mathrm{K}^{+}$ concentrations were 0$), \Delta \mathrm{K}^{+} / \Delta \mathrm{CO}$ ranged from 1.2 to $3.9 \mathrm{pptv}_{\mathrm{ppbv}}{ }^{-1}\left(\right.$ mean $\left.=2.07 \mathrm{pptv}_{\mathrm{ppbv}}{ }^{-1}\right)$. These ratios are generally consistent, although somewhat lower than those reported in other studies (Andreae and Crutzen, 1997; Ma et al., 2003; Reiner et al., 2001), where ratios were in the range of 1.3 to $4.9 \mathrm{pptv}_{\mathrm{ppbv}}{ }^{-1}$. Minor differences in $\mathrm{K}^{+}$relative to $\mathrm{CO}$ compared to other studies could be due to differences in emissions (material and method of burning), and the fact that in some cases the plumes had undergone long-range transport with evidence for precipitation scavenging (Wollny et al., $2007^{2}$ ), a process that may have depleted the particulate $\mathrm{K}^{+}$relative to $\mathrm{CO}$ (Brock et al., 2007 ${ }^{1}$; de Gouw et al., 2006; Warneke et al., 2006). Thus, we conclude the lack of $\mathrm{K}^{+}$in the observed biomass burning plumes was due to expected concentrations near or below the LOD, rather than a complete absence of $\mathrm{K}^{+}$.

\subsection{Air mass classification}

Sulfate, ammonium, WSOC, and aerosol volume varied significantly from their means and medians reflecting high spatial variability over the region sampled (Table 1). To investigate the physico-chemical properties of $\mathrm{PM}_{1.0}$ from different sources, in the following analysis the data are divided into air masses with and without a clear indication of a biomass burning influence. Biomass burning emissions were identified using acetonitrile as a unique tracer (de Gouw et al., 2003), with acetonitrile concentrations below $250 \mathrm{pptv}$ indicating minimal biomass burning influence. In a few cases, biomassburning emissions from long range transport appeared to have mixed with more regionally polluted air masses. These air masses were encountered near the surface and contained fine particles with high inorganic ion concentrations (e.g. ammonium and sulfate), and both high acetonitrile and WSOC concentrations.

\subsubsection{Segregation of data into three air masses types}

In the following analysis, the data are binned into three groups: 1) relatively pure biomass burning air masses acetonitrile concentrations greater than $250 \mathrm{pptv}$ and sulfate less than $4 \mu \mathrm{g} \mathrm{m}^{-3}$;2) sulfate-enhanced biomass burning air masses - acetonitrile greater than $250 \mathrm{pptv}$, and sulfate concentrations greater than $4 \mu \mathrm{g} \mathrm{m}^{-3}$; and 3) non-biomass burning influenced air masses - acetonitrile concentrations less than 250 pptv. (Note that 250 pptv level of acetonitrile was chosen to select for plumes which were strongly influenced by biomass burning; while plumes with lower concentrations (e.g. 0-250 pptv) may have been influenced by biomass burning, this analysis focuses on biomass burning air masses that were relatively pure and contain high concentrations of acetonitrile. Also, $4 \mu \mathrm{g} / \mathrm{m}^{3}$ of sulfate is chosen as the cutoff since it is the approximate average sulfate concentration observed throughout all altitudes in this study. The identification of the pure and sulfate-enhanced biomass burning air masses is not sensitive to this number). These three generalized air masses were observed multiple times in different locations throughout the experiment. 
Table 1. Statistical overview of observed species throughout all flights during NEAQS separated into three bins: All altitudes (top), samples below $2000 \mathrm{~m}$ (middle), and samples above $2000 \mathrm{~m}$ (bottom). For statistical purposes, 1/2 the LOD value is substituted when observation was below LOD. Inorganic ions are sampled over a 90-s averaging time. Fine Volume is averaged to PILS-IC integration time (90s) with estimated water content (see text) subtracted, and WSOC is averaged over $60 \mathrm{~s}$. (For Min column, most data is 1/2 LOD). For fine particle mass, calculated density, calculated OM, OM/PM mass, and Sulfate/PM mass, all data was averaged to PILS-IC integration time (90 s). WSOC was converted to $\mathrm{OM}$ using $\mathrm{C}_{\mathrm{WSOC}}=3.1$; see mass closure section for additional methodology. All statistics include biomass burning data except numbers in parentheses (biomass data is excluded for these calculations/estimations).

\begin{tabular}{|c|c|c|c|c|c|c|c|}
\hline \multicolumn{8}{|l|}{ All Altitudes } \\
\hline & $\mathrm{LOD}^{\mathrm{a}, \mathrm{b}}$ & $\%$ above LOD & Mean & Median & Std Dev & Min & Max \\
\hline Chloride $^{\mathrm{a}}$ & 0.02 & $1.7 \%$ & 0.02 & 0.01 & 0.12 & 0.01 & 3.77 \\
\hline Sulfate $^{\mathrm{a}}$ & 0.03 & $97.0 \%$ & 3.98 & 2.07 & 4.69 & 0.04 & 30.96 \\
\hline Nitrate $^{\mathrm{a}}$ & 0.04 & $15.0 \%$ & 0.06 & 0.02 & 0.24 & 0.02 & 4.66 \\
\hline Sodium $^{\mathrm{a}}$ & 0.2 & $1.3 \%$ & 0.1 & 0.1 & 0.1 & 0.1 & 2.7 \\
\hline Ammonium $^{\mathrm{a}}$ & 0.2 & $79.2 \%$ & 1.1 & 0.6 & 1.1 & 0.1 & 6.5 \\
\hline Calcium $^{\mathrm{a}}$ & 0.2 & $0.5 \%$ & 0.1 & 0.1 & 0.0 & 0.1 & 0.7 \\
\hline Potassium $^{\mathrm{a}}$ & 0.5 & $0.1 \%$ & 0.3 & 0.3 & 0.0 & 0.3 & 0.6 \\
\hline Magnesium $^{\mathrm{a}}$ & 0.2 & $0.1 \%$ & 0.1 & 0.1 & 0.0 & 0.1 & 0.4 \\
\hline WSOC $^{\mathrm{b}}$ & 0.1 & $100 \%$ & 2.2 & 1.6 & 2.2 & 0.1 & 25.6 \\
\hline Fine Volume ${ }^{c}$ & $\mathrm{n} / \mathrm{a}$ & $\mathrm{n} / \mathrm{a}$ & 9.30 & 6.80 & 8.65 & 0.18 & 90.89 \\
\hline Fine Particle Mass ${ }^{\mathrm{a}}$ & $\mathrm{n} / \mathrm{a}$ & & $16.23(15.48)$ & $11.27(11.09)$ & $14.23(11.82)$ & $0.06(0.06)$ & $123.1(85.7)$ \\
\hline Calculated Density ${ }^{\mathrm{d}}$ & $\mathrm{n} / \mathrm{a}$ & & $1.47(1.48)$ & $1.48(1.48)$ & $0.10(0.10)$ & $1.22(1.23)$ & $1.71(1.71)$ \\
\hline Calculated $\mathrm{OM}^{\mathrm{a}}$ & $\mathrm{n} / \mathrm{a}$ & & $6.2(5.8)$ & $4.7(4.5)$ & $6.2(3.9)$ & $0.6(0.6)$ & $71.9(31.6)$ \\
\hline OM/PM Mass & $\mathrm{n} / \mathrm{a}$ & & $0.43(0.43)$ & $0.40(0.40)$ & $0.20(0.20)$ & $0.05(0.05)$ & $0.99(0.99)$ \\
\hline Sulfate/PM Mass & $\mathrm{n} / \mathrm{a}$ & & $0.29(0.30)$ & $0.26(0.26)$ & $0.17(0.17)$ & $0.00(0.01)$ & $0.99(0.99)$ \\
\hline \multicolumn{8}{|c|}{ Altitudes less than $2000 \mathrm{~m}$} \\
\hline & $\mathrm{LOD}^{\mathrm{a}, \mathrm{b}}$ & $\%$ above LOD & Mean & Median & Std Dev & Min & Max \\
\hline Chloride $^{\mathrm{a}}$ & 0.02 & $1.2 \%$ & 0.01 & 0.01 & 0.05 & 0.01 & 1.60 \\
\hline Sulfate $^{\mathrm{a}}$ & 0.03 & $98.5 \%$ & 4.97 & 3.18 & 4.92 & 0.04 & 30.96 \\
\hline Nitrate $^{\mathrm{a}}$ & 0.04 & $14.8 \%$ & 0.05 & 0.02 & 0.13 & 0.02 & 2.41 \\
\hline Sodium $^{\mathrm{a}}$ & 0.2 & $0.1 \%$ & 0.1 & 0.1 & 0.0 & 0.1 & 0.6 \\
\hline Ammonium $^{\mathrm{a}}$ & 0.2 & $97.9 \%$ & 1.5 & 1.0 & 1.2 & 0.2 & 6.5 \\
\hline Calcium $^{\mathrm{a}}$ & 0.2 & $0.3 \%$ & 0.1 & 0.1 & 0.0 & 0.1 & 0.7 \\
\hline Potassium $^{\mathrm{a}}$ & 0.5 & $0 \%$ & 0.3 & 0.3 & 0.0 & 0.3 & 0.3 \\
\hline Magnesium $^{\mathrm{a}}$ & 0.2 & $0 \%$ & 0.1 & 0.1 & 0.0 & 0.1 & 0.1 \\
\hline WSOC $^{\mathrm{b}}$ & 0.1 & $100 \%$ & 2.0 & 0.8 & 4.0 & 0.1 & 25.6 \\
\hline Fine Volume ${ }^{c}$ & $\mathrm{n} / \mathrm{a}$ & $\mathrm{n} / \mathrm{a}$ & 9.62 & 7.63 & 6.53 & 0.64 & 37.31 \\
\hline Fine Particle Mass ${ }^{\mathrm{a}}$ & $\mathrm{n} / \mathrm{a}$ & & $16.35(16.29)$ & $12.13(11.87)$ & $11.87(11.87)$ & $0.06(0.06)$ & $85.70(85.70)$ \\
\hline Calculated Density ${ }^{\mathrm{d}}$ & $\mathrm{n} / \mathrm{a}$ & & $1.48(1.48)$ & $1.48(1.48)$ & $0.10(0.10)$ & $1.24(1.24)$ & $1.71(1.71)$ \\
\hline Calculated $\mathrm{OM}^{\mathrm{a}}$ & $\mathrm{n} / \mathrm{a}$ & & $6.1(6.0)$ & $5.0(5.0)$ & $4.0(4.0)$ & $0.6(0.6)$ & $31.6(31.6)$ \\
\hline OM/PM Mass & $\mathrm{n} / \mathrm{a}$ & & $0.43(0.43)$ & $0.40(0.40)$ & $0.20(0.20)$ & $0.05(0.05)$ & $0.98(0.98)$ \\
\hline Sulfate/PM Mass & $\mathrm{n} / \mathrm{a}$ & & $0.29(0.29)$ & $0.26(0.26)$ & $0.17(0.17)$ & $0.01(0.01)$ & $0.97(0.97)$ \\
\hline \multicolumn{8}{|c|}{ Altitudes greater than $2000 \mathrm{~m}$} \\
\hline & $\mathrm{LOD}^{\mathrm{a}, \mathrm{b}}$ & $\%$ above LOD & Mean & Median & Std Dev & Min & Max \\
\hline Chloride $^{\mathrm{a}}$ & 0.02 & $2.8 \%$ & 0.03 & 0.01 & 0.20 & 0.01 & 3.77 \\
\hline Sulfate ${ }^{\mathrm{a}}$ & 0.03 & $94.6 \%$ & 1.03 & 0.35 & 1.96 & 0.04 & 16.33 \\
\hline Nitrate $^{\mathrm{a}}$ & 0.04 & $15.6 \%$ & 0.11 & 0.02 & 0.40 & 0.02 & 4.66 \\
\hline Sodium $^{\mathrm{a}}$ & 0.2 & $2.5 \%$ & 0.1 & 0.1 & 0.1 & 0.1 & 2.7 \\
\hline Ammonium $^{\mathrm{a}}$ & 0.2 & $38.2 \%$ & 0.7 & 0.5 & 0.7 & 0.2 & 4.3 \\
\hline Calcium $^{\mathrm{a}}$ & 0.2 & $0.6 \%$ & 0.1 & 0.1 & 0.0 & 0.1 & 0.7 \\
\hline Potassium $^{\mathrm{a}}$ & 0.5 & $0.2 \%$ & 0.3 & 0.3 & 0.0 & 0.3 & 0.6 \\
\hline Magnesium $^{\mathrm{a}}$ & 0.2 & $0.1 \%$ & 0.1 & 0.1 & 0.0 & 0.1 & 0.4 \\
\hline WSOC $^{\mathrm{b}}$ & 0.1 & $100 \%$ & 2.2 & 1.8 & 1.6 & 0.2 & 10.7 \\
\hline Fine Volume $e^{c}$ & $\mathrm{n} / \mathrm{a}$ & $\mathrm{n} / \mathrm{a}$ & 7.13 & 1.52 & 17.07 & 0.18 & 90.89 \\
\hline Fine Particle Mass ${ }^{\mathrm{a}}$ & $\mathrm{n} / \mathrm{a}$ & & $15.07(6.85)$ & $4.88(4.08)$ & $28.13(6.78)$ & $0.08(0.08)$ & $123.10(26.89)$ \\
\hline Calculated Density $^{\mathrm{d}}$ & $\mathrm{n} / \mathrm{a}$ & & $1.44(1.45)$ & $1.42(1.45)$ & $0.13(0.12)$ & $1.22(1.23)$ & $1.69(1.69)$ \\
\hline Calculated $\mathrm{OM}^{\mathrm{a}}$ & $\mathrm{n} / \mathrm{a}$ & & $7.8(3.2)$ & $3.3(2.9)$ & $15.8(1.8)$ & $0.6(0.6)$ & $71.9(10.7)$ \\
\hline OM/PM Mass & $\mathrm{n} / \mathrm{a}$ & & $0.46(0.39)$ & $0.42(0.34)$ & $0.23(0.24)$ & $0.06(0.06)$ & $0.99(0.99)$ \\
\hline Sulfate/PM Mass & $\mathrm{n} / \mathrm{a}$ & & $0.30(0.34)$ & $0.28(0.31)$ & $0.23(0.21)$ & $0.00(0.02)$ & $0.99(0.99)$ \\
\hline
\end{tabular}

${ }^{\mathrm{a}}$ In $\mu \mathrm{g} \mathrm{m}^{-3}$ for ions; ${ }^{\mathrm{b}}$ in $\mu \mathrm{g}$ Carbon $\mathrm{m}^{-3} ;{ }^{\mathrm{c}}$ in $\mu \mathrm{m}^{3} \mathrm{~cm}^{-3} ;{ }^{\mathrm{d}} \mathrm{g} \mathrm{cm}^{-3}$. 


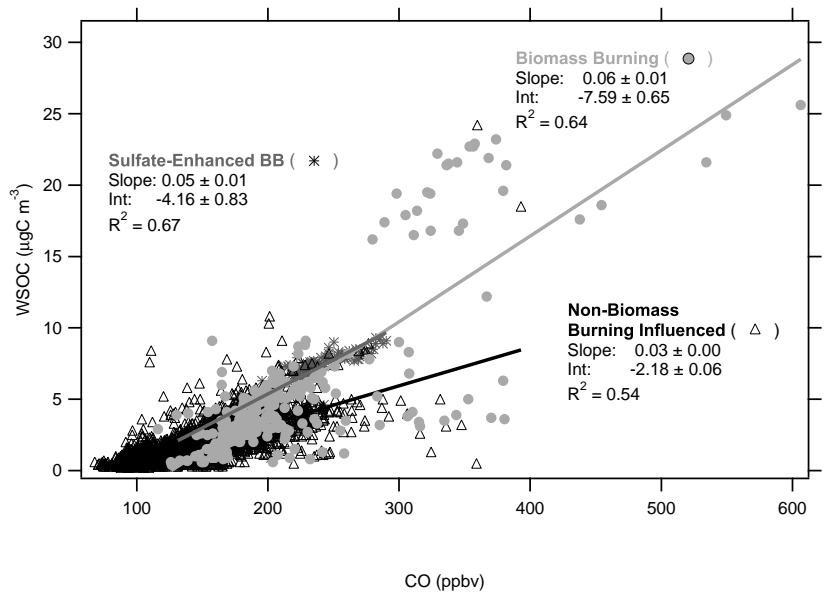

Fig. 2. WSOC plotted as a function of $\mathrm{CO}$, classified by air mass regime. Lines are univariate least-squares linear regression fits. Slope and $r^{2}$ for all plotted data were 0.038 and 0.61 , respectively. Individual regime slope, intercept, and $r^{2}$ values are described in legend. CO data were averaged to 60 seconds to match WSOC integration time.

\subsubsection{Sources of WSOC}

The sources of anthropogenic WSOC are investigated in greater detail by Sullivan et al. (2006), Peltier et al. (2007), and Brock et al. (2007) ${ }^{1}$ and are discussed only briefly here. FLEXPART (Stohl et al., 1998) transport model shows that the larger biomass burning plumes encountered originated from fires in the Alaska/Yukon region (de Gouw et al., 2006; Pfister et al., 2005; Warneke et al., 2006). The highest $\mathrm{PM}_{1.0}$ volumes in this study were observed in these distinct biomass burning plume layers. WSOC and acetonitrile were well correlated in these plumes $\left(r^{2}=0.73\right)$, but were not correlated $\left(r^{2}=0.06\right)$ when acetonitrile was below $250 \mathrm{pptv}$ in air masses with minimal biomass burning influence. Correlations between WSOC and carbon monoxide (CO) were observed throughout this study and suggest a WSOC source linked in some manner to combustion emissions. Other studies (de Gouw et al., 2005; Sullivan et al., 2006; Weber et al., 2007) identify a significant source of WSOC from secondary organic aerosol production. Incomplete combustion is a significant source for $\mathrm{CO}$ and can occur in burning of biomass materials (Chow et al., 1994) or fossil fuels combustion (Mayol-Bracero et al., 2002). The CO-WSOC correlation was observed in all the types of air masses investigated with $r^{2}=0.64$ in relatively pure biomass burning plumes, $r^{2}=0.67$ in biomass burning emissions mixed with sulfate, and $r^{2}=0.54$ in air masses with no biomass burning influence (Fig. 2).

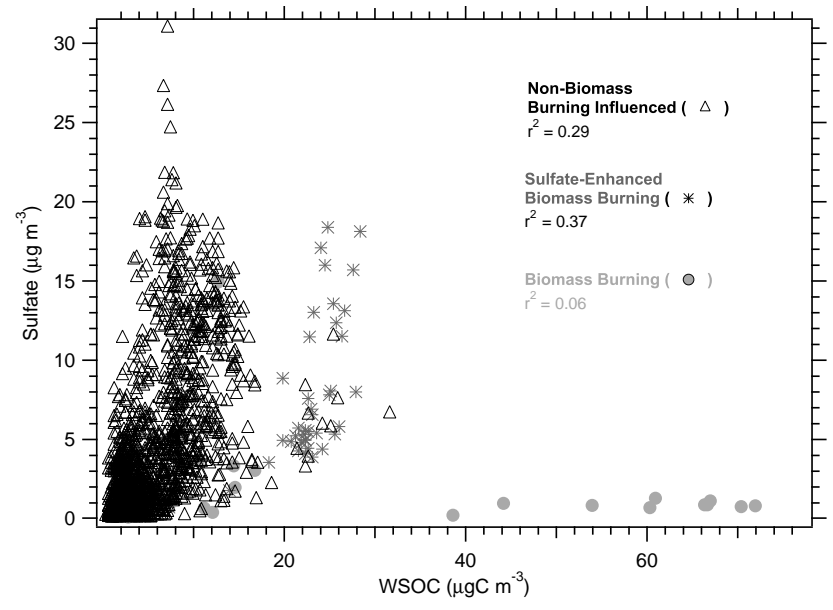

Fig. 3. Sulfate plotted as a function of WSOC for all flights, classified by air mass regime. WSOC data were averaged to $90 \mathrm{~s}$ to match sampling time of sulfate.

\subsubsection{Sulfate sources}

As expected, high sulfate concentrations detected in this study were linked to power plant plume emissions. The urban plumes also often contained sulfate, mainly from sources of $\mathrm{SO}_{2}$ near the urban centers (Brock et al, manuscript in preparation, 2007). Very distinct power plant plumes of high sulfate and $\mathrm{SO}_{2}$ were also encountered away from urban sources. For example, high sulfate mass was observed in the Ohio River Valley region of the U.S. at altitudes less than $\sim 2000 \mathrm{~m}$. This region has many power generation facilities that emit $\mathrm{SO}_{2}$ and were the apparent sources for the observed sulfate. Sulfate and WSOC measured in the regions of western Pennsylvania are discussed in more detail (Sect. 4) where results from a specific flight are presented.

\subsubsection{WSOC-sulfate correlations}

WSOC and sulfate were not highly correlated in the regions sampled. The highest correlation of sulfate-WSOC was observed in the sulfate-enhanced biomass burning air mass $\left(r^{2}=0.37\right)$ where biomass plumes from long range transport had mixed with regionally polluted air masses (Fig. 3). WSOC-sulfate $r^{2}$ within the biomass burning plumes was low $\left(r^{2}=0.06\right)$, while WSOC-sulfate $r^{2}=0.29$ in non-biomass burning regimes. This suggests that WSOC and sulfate did not have co-located sources, or are subjected to highly different removal efficiencies.

\subsection{Sulfate, WSOC, versus fine particle volume}

Although species-specific aerosol chemical mass fractions are of most interest, we first compare speciated mass to particle volume since this only involves directly measured quantities. In the next section, the particle mass is estimated from 

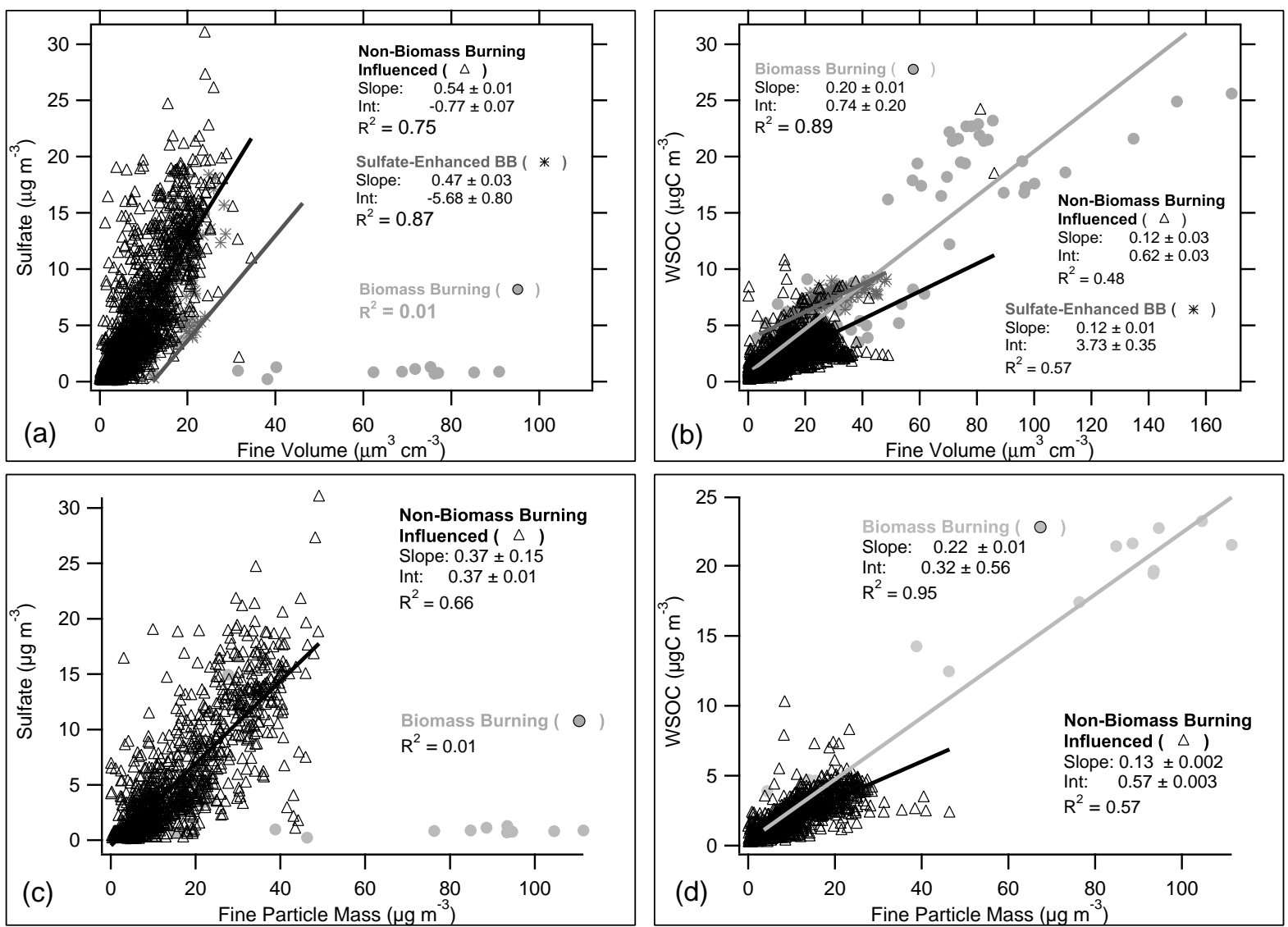

Fig. 4. Sulfate (a) and WSOC (b) plotted as a function of submicron particle volume. Sulfate (c) and WSOC (d) plotted as function of estimated fine particle mass (see text). Symbols indicated data assigned to non-biomass burning, sulfate-enhanced biomass burning, and biomass burning classifications. Lines and legends give univariate linear least-squares regression fits and statistics for each regime. Fine particle volume averaged to $90 \mathrm{~s}$ in (a), and $60 \mathrm{~s}$ in (b) to match integration time of respective measurements. Fine particle volume averaged to $90 \mathrm{~s}$ in (c) and (d) to match integration time of ion measurement. In (c) and (d), cation data were unavailable for sulfate-enhanced biomass burning case; these data are not plotted.

the particle volume, and sulfate and carbonaceous mass fractions are then estimated.

The mean ratio of sulfate to fine particle volume, was $0.54 \mu \mathrm{g} \mathrm{m}^{-3} / \mu \mathrm{m}^{3} \mathrm{~cm}^{-3}$ and these two parameters were highly correlated $\left(r^{2}=0.75\right)$ in samples without a biomass burning influence. For the sulfate-influenced biomass burning plume, the ratio of sulfate to fine particle volume was $0.47 \mu \mathrm{g} \mathrm{m}^{-3} / \mu \mathrm{m}^{3} \mathrm{~cm}^{-3}$, and was also highly correlated $\left(r^{2}=0.87\right)$. The biomass burning plumes that had not mixed to the surface had a different aerosol profile; sulfate was not a significant fraction of fine particle volume and thus was not correlated $\left(r^{2}=0.01\right.$, Fig. 4$)$ with fine particle volume.

In contrast, WSOC was highly correlated $\left(r^{2}=0.89\right)$ with fine particle volume within biomass burning plumes, with a WSOC to fine volume ratio of $0.20 \mu \mathrm{gC} \mathrm{m} \mathrm{m}^{-3} / \mu \mathrm{m}^{3} \mathrm{~cm}^{-3}$. This may not represent typical emission ratios since it may have been altered during transport due to precipitation scavenging (de Gouw et al., 2006). The ratio of WSOC to fine particle volume was lower $\left(0.12 \mu \mathrm{gC} \mathrm{m}^{-3} / \mu \mathrm{m}^{3} \mathrm{~cm}^{-3}\right)$ in non-biomass burning plumes and in sulfate enhanced biomass burning plumes (Fig. 4).

The majority of measurements made during this campaign were non-biomass burning influenced and were likely representative of typical conditions observed in the northeastern United States during the summer of 2004. For all data, and based on regression analysis, sulfate was highly correlated with $\mathrm{PM}_{1.0}$ volume in the regions sampled $\left(r^{2}=0.75\right)$, while WSOC was less well correlated $\left(r^{2}=0.57\right)$. An example of the relative importance of sulfate and WSOC in controlling total submicron particle mass is discussed in a case study in Sect. 4.

\subsection{Calculation of fine particle mass and organic mass from} volume and WSOC measurements

In this section, the WSOC to OM (organic matter) ratio, $\mathrm{C}_{\mathrm{WSOC}}$, is estimated and then used in subsequent analysis to convert WSOC to OM. For this purpose, fine particle volume 


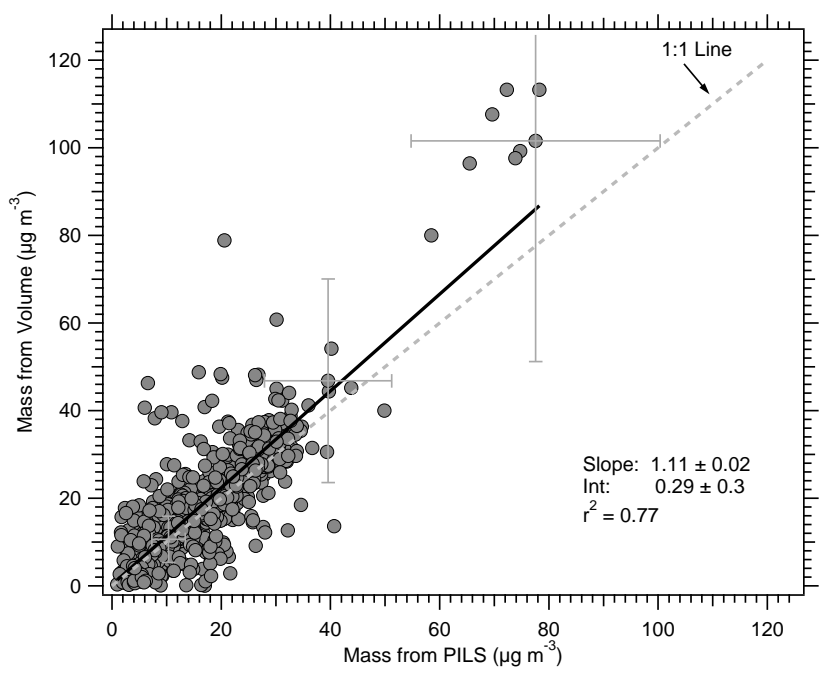

Fig. 5. Particle mass estimated from submicron volume measurements plotted as a function of mass from directly measured composition (see text). Error bars are instrument uncertainties propagated in quadrature.

and PILS-WSOC data were averaged to $90 \mathrm{~s}$, the time integral of PILS-IC measurements. All data (including biomass burning interceptions) from this field campaign are included in this calculation. Assuming a constant density for organic aerosol mass and a constant WSOC to OM ratio $\left(\mathrm{C}_{\mathrm{WSOC}}\right)$, sulfate and $\mathrm{OM}$ fractions of $\mathrm{PM}_{1.0}$ mass are calculated and summarized (Table 1).

To calculate mass from submicron particle volume, no correction is made for the effect of composition on the optical measurements (e.g. influence on particle refractive index). We assume a particle density of $1.78 \mathrm{~g} \mathrm{~cm}^{-3}$ for inorganic ionic aerosol mass (e.g., ammonium sulfate and ammonium bisulfate), and a density of $1.2 \mathrm{~g} \mathrm{~cm}^{-3}$ for the organic aerosol component (Turpin and Lim, 2001). The overall density was determined by a volume-weighted average based on concentrations of the measured inorganic ions and OM. Fine particle volume was reported at $\sim 40 \%$ relative humidity, and thus included condensed water vapor in the particle volume measurement. This was quantified by assuming all condensed water was associated with the measured $\mathrm{NH}_{4}^{+}$and $\mathrm{SO}_{4}^{2-}$ and using the model ISORROPIA (Nenes et al., 1998). The predicted water volume associated with the particle at the measurement relative humidity of $40 \%$ was subtracted from the particle volume measurement.

Conversion of WSOC to organic matter (OM) can be accomplished by calculating a ratio of OM to WSOC (units: $\left.\mu \mathrm{g} \mu \mathrm{gC}^{-1}\right)$. This conversion factor has two components: one accounts for the insoluble portion of carbon mass associated with the organic carbon (OC) that was unmeasured (OC/WSOC, units: $\mu \mathrm{gC} \mu \mathrm{gC}^{-1}$ ); the second factor converts organic carbon (OC) to organic matter (OM) (OM/OC, units: $\mu \mathrm{g} \mu \mathrm{gC}^{-1}$ ), which accounts for the elemental groups (e.g., oxygen, nitrogen, hydrogen, etc.) that are associated with the carbon. The ratio of summertime WSOC/OC from a variety of studies has been reported by Jaffrezo et al. (2005, references therein) to range from $31 \%-77 \%$, with lower ratios generally found in fresh plumes and higher ratios in more aged plumes. In addition, as reported by Turpin and Lim (2001), OM/OC ratios range from 1.6 (urban) to 2.1 (non-urban, more aged). The relationship between particle age and OM/WSOC ratio is complicated in that as a particle ages, the WSOC/OC component increases (i.e. OC/WSOC decreases) while the OM/OC component increases. This creates conditions where the calculation of the OM/WSOC ratio, defined as $\mathrm{OM} / \mathrm{WSOC}=(\mathrm{OM} / \mathrm{OC}) \times(\mathrm{OC} / \mathrm{WSOC})$, is somewhat self-compensating resulting in a smaller variability of OM/WSOC than otherwise might be expected.

The mass calculated from fine particle volume $\left(\mathrm{PM}_{\mathrm{vol}}\right)$ can be compared to that observed by PILS (PMPILS) by Eq. (1):

$$
\begin{aligned}
V_{\text {fine }} & \times\left(\frac{\left(\mathrm{C}_{\mathrm{WSOC}} \times \mathrm{WSOC}\right)+\sum \text { ion }}{\left(\frac{\mathrm{C}_{\mathrm{WSOC}} \times \mathrm{WSOC}}{\rho \mathrm{om}}\right)+\frac{\sum \text { ion }}{\rho \text { ion }}}\right) \\
& =\left(\sum \text { ion }+\left(\mathrm{C}_{\mathrm{WSOC}} \times \mathrm{WSOC}\right)+\mathrm{M}_{\text {unmeasured }}\right)
\end{aligned}
$$

This equation includes terms that describe fine particle volume $\left(V_{\text {fine }}\right)$, weighted density of organic matter and ions $\left(\rho_{\text {om }}\right.$ and $\left.\rho_{\text {ion }}\right)$, sum of measured ions $\left(\Sigma_{\text {ion }}\right)$, organic matter, which is defined as WSOC multiplied by $\mathrm{C}_{\mathrm{WSOC}}$, and an estimate of the unmeasured fraction that may include species such as elemental carbon, metals, and crustal material $\left(\mathrm{M}_{\text {unmeasured }}\right)$. Rearranging the mass balance equation and using an iterative equation solver, the balance equation can be solved for $\mathrm{C}_{\mathrm{WSOC}}$. Occasionally ( $<4 \%$ of calculations), $\mathrm{C}_{\mathrm{WSOC}}$ was less than 1 (OM less than WSOC); these data, which are likely associated with instrumental uncertainties, are excluded from this analysis. The median $\mathrm{C}_{\mathrm{WSOC}}$ ratio $( \pm 1 \sigma)$ for all data was $3.1( \pm 1.6) \mu \mathrm{gC} \mu \mathrm{g}^{-1}$. The sum of squares of the uncertainty associated with each measurement (particle volume, anion, cation, WSOC) results in an overall uncertainty of $\sim 50 \%$ in this value. Using $\mathrm{C}_{\mathrm{WSOC}}=3.1$, $\mathrm{PM}_{\mathrm{vol}}$ and PMPILS are highly correlated $\left(r^{2}=0.77\right.$, Fig. 5) for all data recorded during this mission. There were no discernable patterns for the WSOC-to-OM ratio across sampled longitude, latitude, or altitudes.

The derived value $\mathrm{C}_{\mathrm{WSOC}}=3.1$ is similar to what is expected based on reasonable values of $\mathrm{WSOC} / \mathrm{OC}$ and $\mathrm{OM} / \mathrm{OC}$ previously discussed. For example, a value of $\mathrm{C}_{\mathrm{WSOC}}=3.1 \mathrm{can}$ be derived if $\mathrm{OM} / \mathrm{OC}$ is presumed to be 1.9 and WSOC is $61 \%$ of OC. This is consistent with what has been found in other studies. For example, in St. Louis, MO, a summer time WSOC/OC ratio of $\sim 61$ to $64 \%$ is reported by Sullivan et al. (Sullivan et al., 2004) and OM/OC of 1.95 \pm 0.17 (Bae et al., 2006).

Recall that the calculated ratio from mass balance assumes an unmeasured aerosol volume as $8 \%$. Using data from EPAs Interagency Monitoring of Protected Visual Environments 

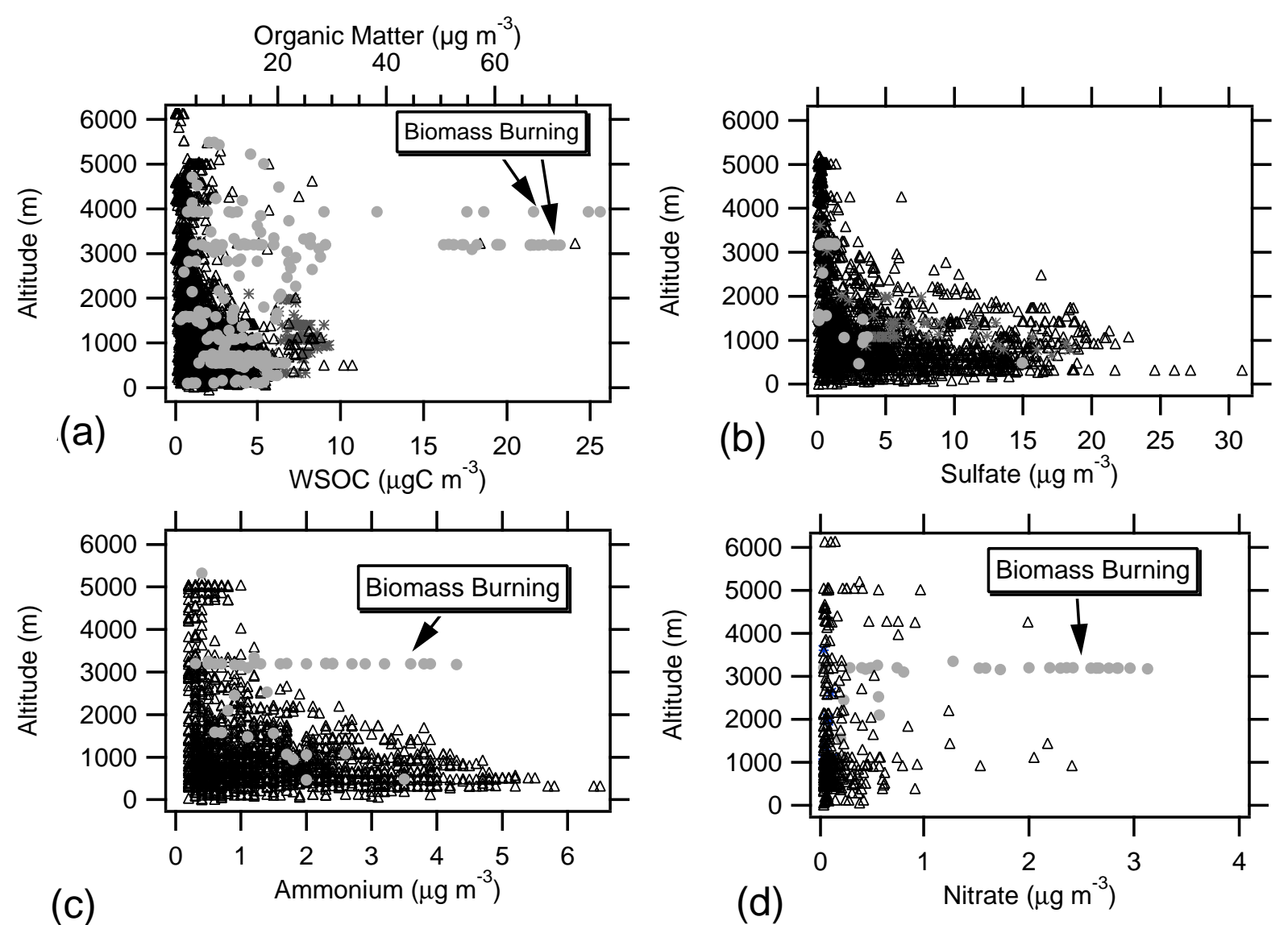

\begin{tabular}{|cl|}
\hline$\triangle$ & Non-Biomass Burning Influenced \\
0 & Biomass Burning \\
$*$ & Sulfate-Enhanced Biomass Burning \\
\hline
\end{tabular}

Fig. 6. Altitude profiles for WSOC (and estimated OM), sulfate, ammonium, and nitrate ion. Specific biomass plumes are indicated.

(IMPROVE) sites located within the sampling region, elemental carbon was, on average, observed to be less than $\sim 5 \%$ of $\mathrm{PM}_{2.5}$ mass at the IMPROVE ground sites; metals and crustal materials at the IMPROVE sites account for an additional $2-3 \%$ of $\mathrm{PM}_{2.5}$ mass. None of these compounds were measured aboard the WP-3D aircraft. The IMPROVE data are only used as an estimate of the unmeasured aerosol in order to complete the mass closure and may not be fully representative of the conditions sampled by the WP-3D; IMPROVE sites tend to measure background concentrations of aerosol whereas the WP-3D focused mainly on specific power plant and urban plumes. If the fraction of unmeasured aerosol was larger than $8 \%, \mathrm{C}_{\mathrm{WSOC}}$ would be slightly lower.

The influence of particle chemical composition on this mass comparison was investigated by segregating the data into periods when the constructed chemical mass was dominated by either sulfate mass or WSOC (and thus OM). For data in which sulfate was less than $25 \%$ of the mass inferred from the chemically speciated measurements (for these cases
WSOC was, on average, approximately three times the mass of sulfate) $\mathrm{C}_{\mathrm{WSOC}}$ is $3.3 \pm 1.9$. In contrast, for data where sulfate was greater than $80 \%$ of the mass, $\mathrm{C}_{\mathrm{WSOC}}$ is $2.8 \pm 1.4$.

Surprisingly, the derived value of $\mathrm{C}_{\mathrm{WSOC}}$ was similar for biomass burning plumes and non-biomass burning. In biomass burning plumes (acetonitrile concentration above 250 pptv), the $\mathrm{C}_{\mathrm{WSOC}}$ was $3.3 \pm 1.3$ and $3.0 \pm 1.7$ for outside of biomass burning plumes (acetonitrile concentration below $250 \mathrm{pptv})$. Higher values of $\mathrm{C}_{\mathrm{WSOC}}$ within biomass burning plumes are consistent with additional insoluble organics not included in the WSOC measurement.

Using the results of this analysis, Table 1 describes aerosol statistics after converting WSOC to OM and calculating mass from fine particle volume. Estimated condensed water was subtracted from the fine particle volume measurement. Across all altitudes, the calculated median concentration of submicron particle mass was $11.27 \mu \mathrm{g} \mathrm{m}^{-3}$. Median fine particle mass concentration was higher at lower altitudes $\left(12.13 \mu \mathrm{g} \mathrm{m}^{-3}\right)$ and lower at higher altitudes 

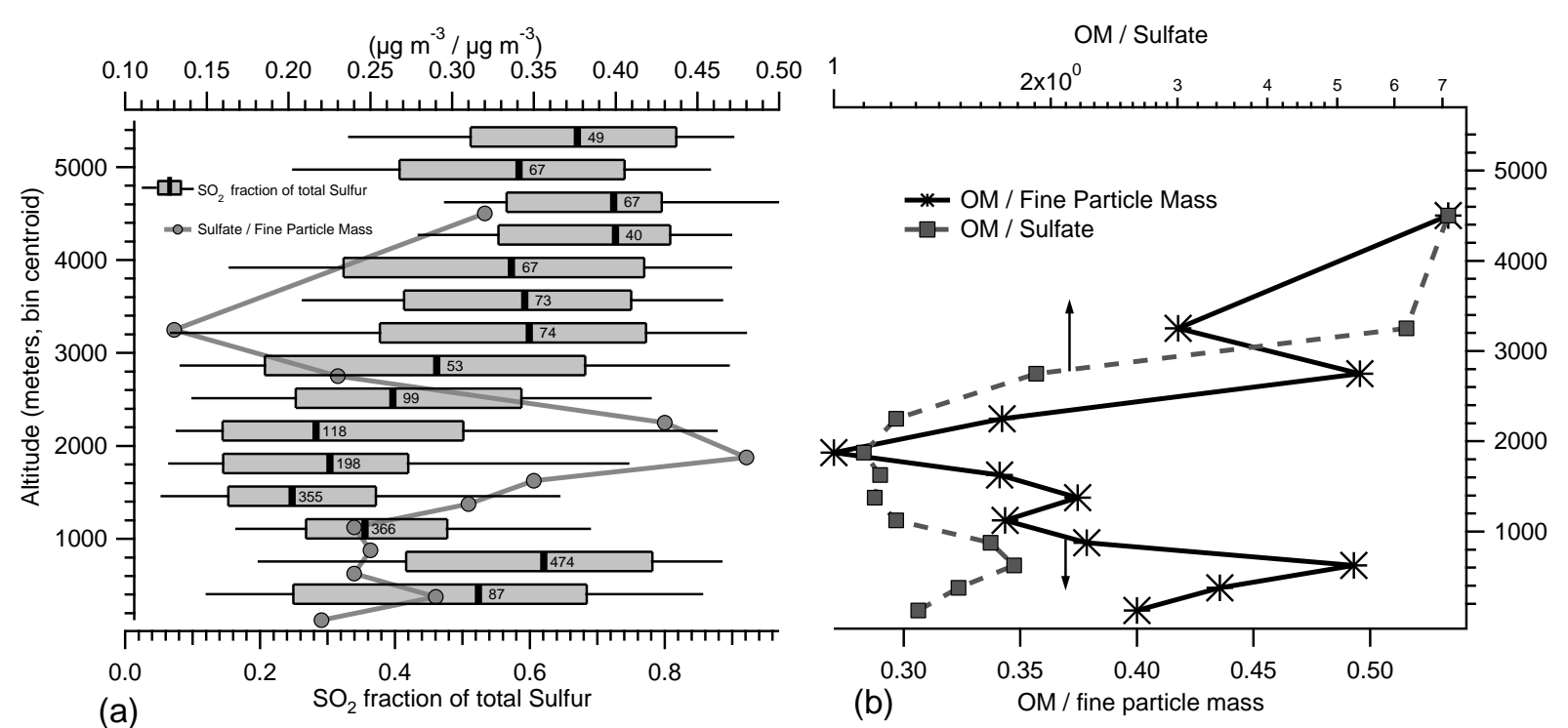

Fig. 7. (a) Altitude profile of ratio of sulfate to fine particle mass (grey line, top axis), and $\mathrm{SO}_{2}$ fraction of total observed sulfur (box and whisker plot, bottom axis). Markers represent median data point of $250 \mathrm{~m}$ binned data at altitudes less than $2000 \mathrm{~m}$, and $500 \mathrm{~m}$ binned data at altitudes greater than $2000 \mathrm{~m}$. Box and whisker plot gives, 10th and 90th percentiles (ends of whiskers), 25th and 75th percentile (ends of boxes), median value (dark line), and number of observations within each bin (to immediate right of median line). (b) Altitude profiles of ratio of organic matter $(\mathrm{OM})$ to fine particle mass. Organic matter/sulfate is also plotted (dashed line). Biomass burning samples have been excluded from this analysis.

(4.88 $\mu \mathrm{g} \mathrm{m}^{-3}$, though with a significant standard deviation due to biomass burning plumes). Average particle density, which was weighted by particle composition determined by PILS, was $1.47 \mathrm{~g} \mathrm{~cm}^{-3}$. Median density was slightly lower at higher altitudes, consistent with increasing ratios of organic material to fine particle volume (discussed in next section and in Fig. 7) and an assumed organic aerosol density of $1.2 \mathrm{~g} \mathrm{~cm}^{-3}$. On average, organic matter was $6.2 \mu \mathrm{g} \mathrm{m}^{-3}$, although $\mathrm{OM}$ ranged from $0.6 \mu \mathrm{g} \mathrm{m}^{-3}$ to $71.9 \mu \mathrm{g} \mathrm{m}^{-3}$. The median ratio of calculated OM to fine particle mass was $0.40 \mu \mathrm{g} \mathrm{m}^{-3} / \mu \mathrm{g} \mathrm{m}^{-3}$ for the entire dataset and $0.46 \mu \mathrm{g} \mathrm{m}^{-3} / \mu \mathrm{g} \mathrm{m}^{-3}$ above $2000 \mathrm{~m}$ altitude.

Mass fractions of sulfate and WSOC can also be computed. Sulfate (Fig. 4c) represents $\sim 37 \%$ of fine particle mass in non-biomass burning influenced samples (determined by regression slope), providing further evidence that sulfate is a significant fraction of fine particle mass within the sampling domain. WSOC accounts for $22 \%$ $\left(\mu \mathrm{gC} \mathrm{m}^{-3} / \mu \mathrm{g} \mathrm{m}^{-3}\right)$ of fine particle mass in biomass burning sampling, and $13 \%$ in non-biomass burning air masses within the sampling domain (Fig. 4d). Thus, using the WSOCto-OM conversion technique previously discussed, we estimate the organic matter mass fraction of fine particle mass to be $\sim 68 \%\left(\mu \mathrm{g} \mathrm{m}^{-3} / \mu \mathrm{g} \mathrm{m}^{-3}\right)$ in biomass burning plumes and $42 \%$ in non biomass burning air masses.

\subsection{Variation in concentration with altitude}

The NOAA WP-3D aircraft operated in an altitude range of approximately $250 \mathrm{~m}$ to $6100 \mathrm{~m}$ (above sea level). Altitude profiles of sulfate, ammonium, nitrate, and WSOC for all data collected during ICARTT in the northeastern United States are shown in Fig. 6. The sampling region was focused heavily on urban outflow from New York City, NY and Boston, MA, but also included several transects of the Ohio River Valley, US region (approximately $37^{\circ}$ to $41^{\circ} \mathrm{N}$ latitude, $-82^{\circ}$ to $-87^{\circ}$ longitude). Additional sampling was conducted in northern Quebec to sample biomass burning plumes, as well as over the Gulf of Maine and western regions of Canadian Maritimes to sample aged urban air masses. Aircraft interceptions of distinct biomass burning plumes between 3 and $4 \mathrm{~km}$ altitude can be observed in the WSOC (OM), nitrate, and ammonium plots (Fig. 6). Additional discussion of altitude profiles can be found in Sullivan et al. (2006) and Warneke et al. (2006).

In air not significantly influenced by biomass burning, measurement throughout the sampled column showed that sulfate and ammonium concentrations were generally highest at altitudes below $2000 \mathrm{~m}$ (i.e. within the boundary layer). WSOC and estimated OM had a similar profile with highest concentrations near the surface. Aerosol nitrate concentrations did not vary systematically with altitude. Since concentrations of these species, with the exception of nitrate, were highest at lower altitudes, it appears that the major 
sources of sulfate, ammonium, and WSOC are from the surface and that that these compounds are not efficiently dispersed above $\sim 2000 \mathrm{~m}$, a finding supported by a modeling analysis of these data (Heald et al., 2006).

The altitude profile of $\mathrm{SO}_{2}$ (not shown) was similar to that of sulfate, with higher concentrations occurring at lower altitudes. The highest concentrations of $\mathrm{SO}_{2}$ were observed near $1000 \mathrm{~m}(\sim 40 \mathrm{ppbv})$. The profile of $\mathrm{CO}$ (not shown) was similar to WSOC (recall that CO and WSOC are correlated, Fig. 2), and decrease with increasing altitude, $\mathrm{CO}$ approached a background free troposphere concentration of approximately $75 \mathrm{ppbv}$. WSOC was also measured throughout the sampled altitude range. Excluding measurements below $2000 \mathrm{~m}$ and biomass burning interceptions above $2000 \mathrm{~m}$, WSOC measurements were higher than the instrument LOD $35 \%$ of the time (535 samples). Substituting one-half LOD value $\left(0.05 \mu \mathrm{gC} \mathrm{m}^{-3}\right)$ in cases where the measurement was less than LOD (note, in Table 1, the calculated OM does not substitute one-half LOD value, and averages are therefore higher), mean WSOC concentration $( \pm 1 \sigma)$ above the planetary boundary layer was $0.3 \mu \mathrm{gC} \mathrm{m}^{-3}\left( \pm 0.5 \mu \mathrm{gC} \mathrm{m}^{-3}\right)$. Since large sources of WSOC (e.g. biomass burning plumes) are excluded from this calculation, this finding suggests a free troposphere background concentration of WSOC of approximately $0.3 \mu \mathrm{gC} \mathrm{m}^{-3}$. Converting this to organic matter, we estimated the free troposphere concentration of organic matter is approximately $1.0 \mu \mathrm{g} \mathrm{m}^{-3}$. This estimate is consistent with the findings of Heald et al. (2005), Maria et al. (2003), Park et al. (2003) and Jaffe et al. (2005) where background concentrations of organic matter ranged from 0.43 to $\sim 3 \mu \mathrm{g} \mathrm{m}^{-3}$.

Although absolute concentrations of WSOC (and hence, $\mathrm{OM}$ ) and sulfate dropped sharply with increasing altitude, the ratio of sulfate to $\mathrm{OM}$, ratio of sulfate to fine particle mass, and ratio of OM to fine particle mass did not follow this profile. To improve signal, the OM, sulfate, and particle mass data were binned into $250 \mathrm{~m}$ intervals for altitudes less than $2 \mathrm{~km}$ and $500 \mathrm{~m}$ intervals for altitudes greater than $2 \mathrm{~km}$. The median of the ratio was calculated for each bin. The median values for the highest and lowest altitude bins are more uncertain since these bins include fewer data points. In air masses not significantly affected by biomass burning (acetonitrile $<250 \mathrm{pptv}$ ), the median ratio of $\mathrm{SO}_{2}$ to total sulfur $\left(\mathrm{SO}_{2} /\left(\mathrm{SO}_{2}+\right.\right.$ sulfate $\left.)\right)$ and of $\mathrm{SO}_{4}^{2-}$ to fine particle mass $\left(\mu \mathrm{g} \mathrm{m}^{-3} / \mu \mathrm{g} \mathrm{m}^{-3}\right)$ in each altitude bin was calculated (Fig. 7a). Between the altitudes of $\sim 1000-3000 \mathrm{~m}$, $\mathrm{SO}_{2} /\left(\mathrm{SO}_{2}+\right.$ sulfate $)$ was lowest and sulfate/fine particle mass was highest, suggesting that in this altitude range, oxidation of $\mathrm{SO}_{2}$ to particulate sulfate had occurred at a rate faster than that of particle removal processes. Below this altitude, sufficient time may not have occurred since emission to allow for substantial oxidation and sulfate formation. Between 3000 and $4000 \mathrm{~m}$, particle removal processes (such as precipitation scavenging) may have efficiently removed sulfate particles at a rate faster than production of sulfate by $\mathrm{SO}_{2}$ oxidation. Finally, at altitudes $>4000 \mathrm{~m}$, slower removal processes may have resulted in a higher ratio of sulfate to total sulfur.

While absolute concentrations of sulfate and OM were much higher below $3 \mathrm{~km}$ altitude than above this altitude (Fig. 6), the ratio of $\mathrm{OM}$ to fine particle mass $\left(\mu \mathrm{gC} \mathrm{m}^{-3} / \mu \mathrm{g} \mathrm{m}^{-3}\right)$ substantially increased with altitude in the non-biomass burning influenced air masses, with the highest ratios occurring above $3000 \mathrm{~m}$ in the free troposphere (Fig. 7b). The variation in the ratio of $\mathrm{OM}$ to sulfate ion with altitude is also plotted and has a similar profile as the ratio of $\mathrm{OM}$ to $\mathrm{PM}_{1.0}$ mass. This result is consistent with Novakov et al. (1997), who reported an increase of total organic carbon mass fraction as altitude increased from $0-3.5 \mathrm{~km}$ from aircraft measurements near Virginia, US in 1996. Similarly, Murphy et al. (1998) reported that in upper tropospheric (5$19 \mathrm{~km})$ measurements near Texas, internally-mixed aerosol with higher fractions of organics relative to sulfate were observed.

The vertical profile of ratios in composition (Fig. 7b) suggests that relative to sulfate, $\mathrm{OM}$ is either more efficiently lofted, is removed less efficiently, and/or produced in situ at faster rates at altitudes between 3 and $5 \mathrm{~km}$. Compared to sulfate particles, those containing significant mass fractions of OM may be less efficiently activated to form cloud condensation nuclei and thus may not be as likely to undergo wet deposition when lofted. However, Heald et al. (2005) performed a covariance analysis of this data set and suggest that an unknown, possibly heterogeneous, pathway for secondary organic aerosol formation is a likely contributor to free troposphere aerosol mass. Biomass burning, which likely contributes to the observed background concentrations of acetonitrile ( $\sim 200-250 \mathrm{pptv})$, may also be responsible for some of the additional free troposphere OM concentrations that are not fully explained in modeling studies.

\subsection{Charge balance between measured ions}

The spatially heterogeneous and strong emissions of some of the aerosol sources encountered in this study led to wide variability in other aerosol properties, such as balance between measured anions and cations. Comparing concentrations of measured anions to cations can provide insight into the presence of unmeasured ions. In the following analysis, an ion balance is calculated from the sum of measured cations minus the sum of measured anions, in equivalence concentrations. Large positive or negative deviations from zero suggest unmeasured ionic constituents in the sampled aerosol particles. In the following analysis, if a specific ion was at the LOD, the ion was not considered in the ion balance calculation. This is to reduce a bias that would have been caused by differences in cation and anion LODs. Often, a balance between measured anions and cations was observed; however, in many cases the net charge was negative, suggesting an unmeasured cation, most likely $\mathrm{H}^{+}$, suggesting a more acidic 


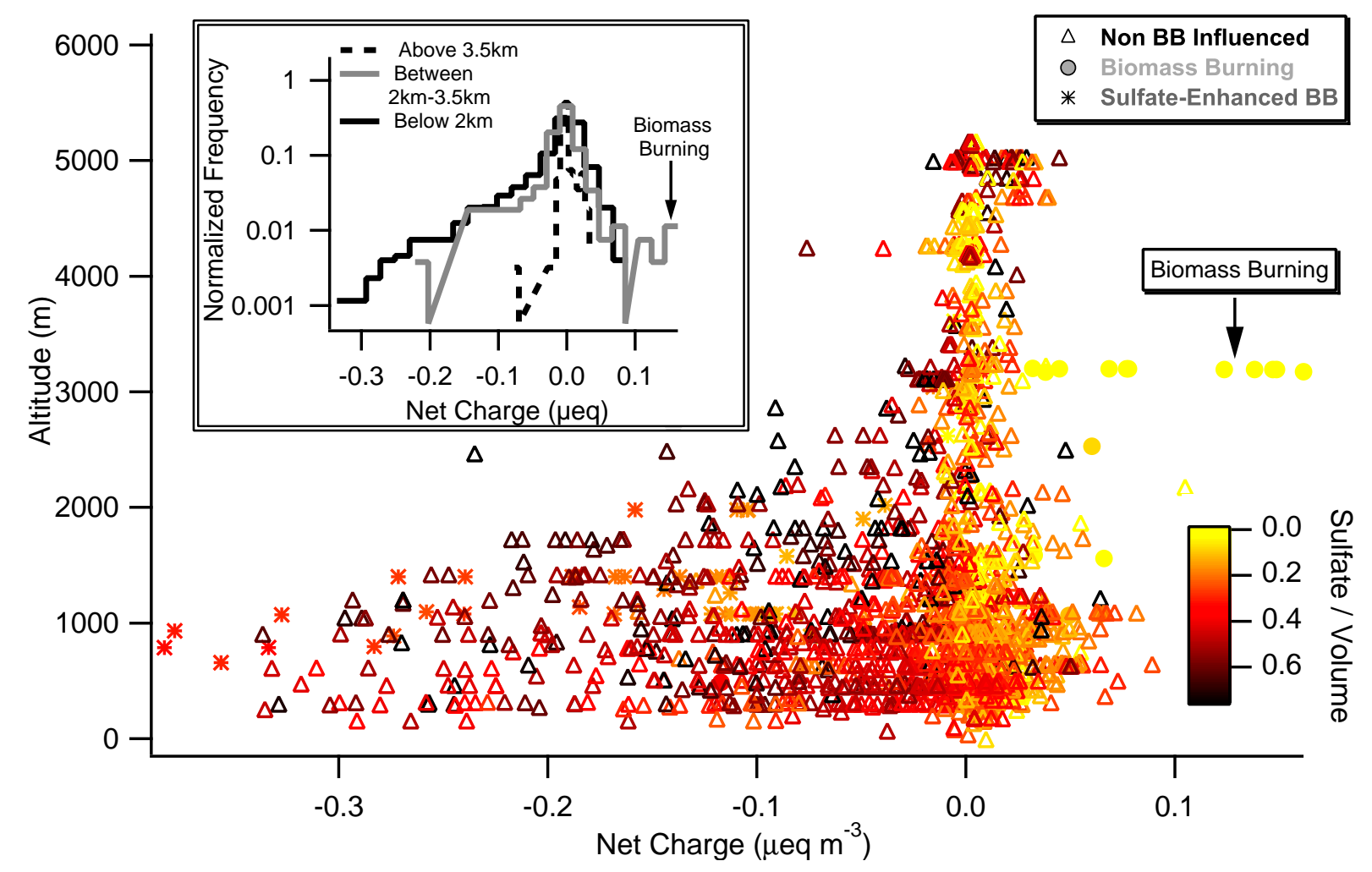

Fig. 8. Altitude profile of charge balance for sulfate, ammonium, and nitrate ions, colored by sulfate fraction of fine particle volume. Values $<$ LOD assigned value of 0 . Embedded plot on upper left is normalized frequency histogram of observed charge balances in 3 altitude ranges (less than $2 \mathrm{~km}, 2-3.5 \mathrm{~km}$, and above $3.5 \mathrm{~km}$ ).

aerosol. Figure 8 illustrates the calculated net charge of observed ions over the altitude range of the measurements. On average, the net charge was zero, indicating that most anioncation pairs were measured (Fig. 8). The charge balance was within the range of -0.05 to $+0.05 \mu \mathrm{eq} \mathrm{m}^{-3} 67 \%$ of the time.

The measured aerosol ion balance is always near zero at altitudes from $3000-5000 \mathrm{~m}$, when biomass burning plumes are excluded. However, many low-altitude charge balance calculations were observed to be highly negative. During periods of highest negative charge balance, sulfate tends to be a larger fraction of $\mathrm{PM}_{1.0}$ volume (Fig. 8). Net charge on the particles also tended to become more negative when absolute concentrations of sulfate increased (not plotted). This implies that strong $\mathrm{SO}_{2}$ sources leading to sulfate formation overwhelm sources for ammonia, the precursor for sulfate's commonly-paired cation species. This was most clearly seen in power generation regions (see Sect. 4).

A composite, normalized histogram that bins all observations of charge balance into three altitudes - low $(<2 \mathrm{~km})$, middle $(2-3.5 \mathrm{~km})$ and high $(>3.5 \mathrm{~km}),-$ shows that a net charge of approximately $0 \mu$ eq was observed most frequently throughout each altitude bin (inset in Fig. 8). In the lowest altitude bin, there is a significant tail toward negative values suggesting a more acidic aerosol composition. Some occur- rences of positive ion balances were observed in the middle altitude range during biomass burning plume interceptions. Biomass burning particles were found to have relatively high ammonium and low sulfate concentrations; thus a net positive charge balance may result from an unmeasured organic acid associated with $\mathrm{NH}_{4}^{+}$. The WSOC concentration, which includes organic acids, is correlated (not plotted) with the positive charge balance in biomass burning plumes $\left(r^{2}=0.58\right)$.

The general chemical and physical characteristics of the sampled fine aerosol have been discussed. Measurements from a specific flight are now investigated in detail.

\section{Case study: nighttime sulfate and WSOC in indus- trial and urban areas}

A nighttime flight on 9 August 2004 presented an opportunity to contrast on a single flight air masses measured over the power generation regions of eastern Ohio and western Pennsylvania to air masses influenced by urban regions on the eastern seaboard. The flight was conducted at night between $\sim 19: 00$ and $\sim 02: 00$ EDT. This flight is also discussed in detail by Brown et al. (2006) where the affect of nocturnal nitrogen oxide processing on air quality was investigated. 

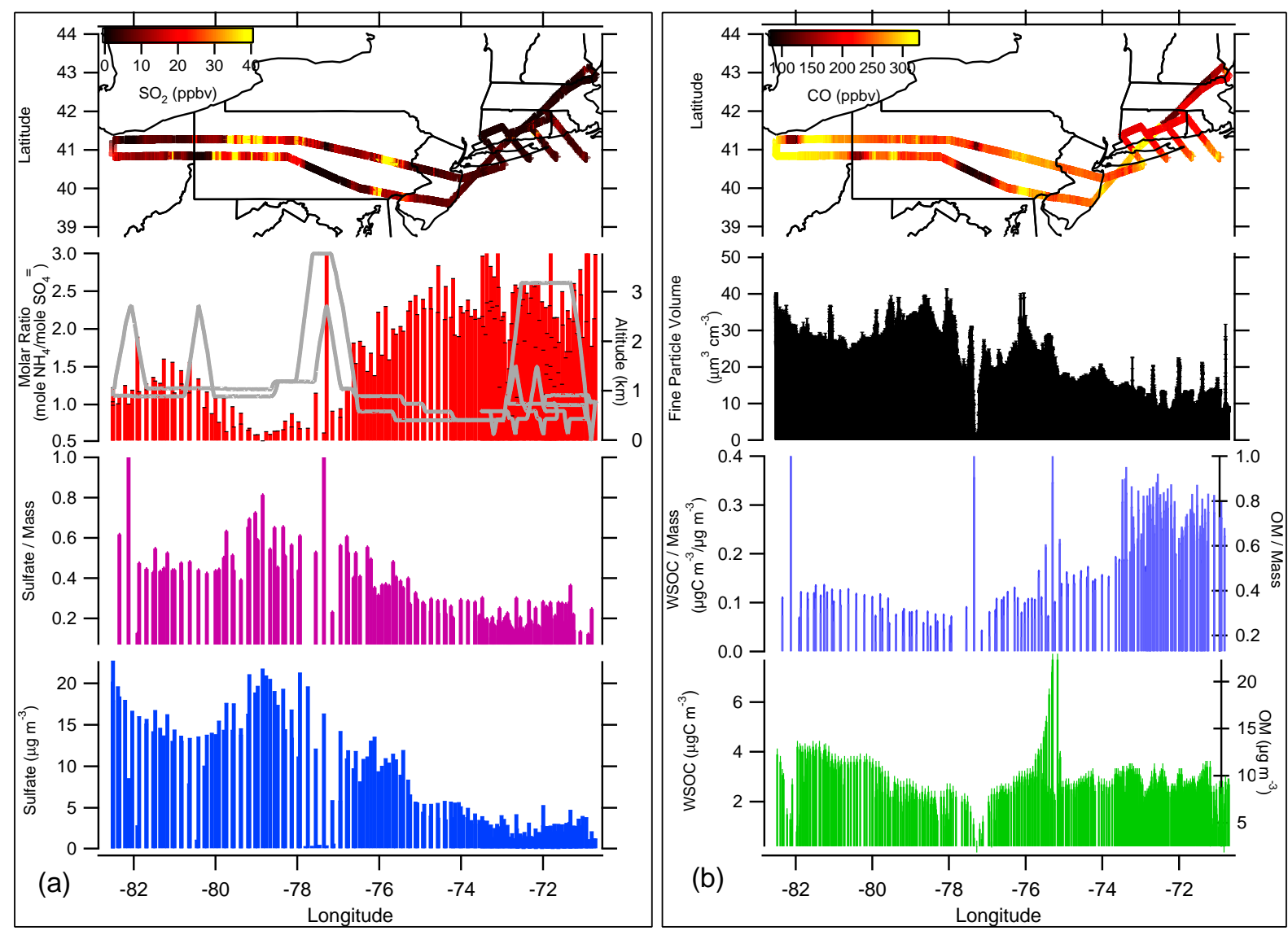

Fig. 9. (a) Track of WP-3D aircraft on 2004/08/09 colored by $\mathrm{SO}_{2}$, and molar ratio, altitude, sulfate fraction of fine particle mass, and sulfate mass as a function of longitude. (b) As in (a), but colored by CO and fine particle volume, WSOC fraction of fine particle mass, and WSOC as a function of longitude.

Figure 9 shows the flight path colored by $\mathrm{SO}_{2}$ and $\mathrm{CO}$, the aircraft altitude, and the observed spatial distribution of fine particle volume, sulfate, WSOC, and ammonium to sulfate $\left(\mathrm{NH}_{4}^{+} / \mathrm{SO}_{4}^{2-}\right)$ molar ratios. The Pennsylvania and eastern Ohio portion of the flight was sampled from approximately 00:00-04:00 UTC (20:00-00:00 EDT). The wind direction was generally from the southwest at $\sim 8 \mathrm{~m} \mathrm{~s}^{-1}$, although direction was more south-southwesterly during the westernmost portions of the flight. Based on the combined transport and emission inventory model FLEXPART (Stohl et al., 1998) $\mathrm{SO}_{2}$ was largely derived from power plants located along the Ohio River and in western Pennsylvania, whereas $\mathrm{CO}$ was generally from the Columbus and Cincinnati Ohio, Detroit, Michigan, and Pittsburgh, Pennsylvania areas. The FLEXPART simulation indicates that both $\mathrm{SO}_{2}$ and $\mathrm{CO}$ were aged approximately 1-4 days since the time of emission.

The eastern seaboard leg included a flight pattern designed to characterize the outflow of New York City from approximately 04:05-07:00 UTC (00:05-03:00 EDT) as the WP-3D returned to Portsmouth, New Hampshire. A FLEXPART analysis for this region shows that the majority of $\mathrm{CO}$ and
$\mathrm{SO}_{2}$ that was observed originated from the New York City metropolitan region. These pollutants were aged generally less than one day. Wind direction was westerly, with average wind speeds around $6 \mathrm{~m} \mathrm{~s}^{-1}$. These nighttime measurements had somewhat low CO concentrations, typically ranging from 150-200 ppbv in the NYC outflow, versus daytime flights where $\mathrm{CO}$ concentrations typically ranged from 230 to 240 ppbv. The Ohio River Valley region had similar CO concentrations, apart from the $200-225$ ppbv of CO observed in the westernmost region of the flight in the vicinity of Columbus and Cleveland, Ohio.

As expected, based on the spatial distribution of coal-fired power plants, sulfate concentrations were factors of four to five times higher over the power generation regions on the western leg of the flight compared to the eastern regions. Fine particle mass was estimated from measured volume as discussed in a previous section. Sulfate was $\sim 60 \%$ and WSOC $\sim 10 \%$ (OM $\sim 33 \%$, assuming OM/WSOC is constant at 3.1, see Sect. 3.4) of total submicron mass in the power generation regions of western Pennsylvania. For all of this flight, the spatial variability in $\mathrm{PM}_{1.0}$ was driven by 
sulfate. WSOC concentrations were more spatially uniform, although slightly higher WSOC, and hence OM, in the extreme western portion of the flight was correlated with higher $\mathrm{CO}$ from Columbus and Cincinnati, Ohio.

High sulfate concentrations in the power production regions of western Pennsylvania ( -80 to $-78^{\circ}$ longitude) produced an apparently acidic aerosol. In these regions $\mathrm{NH}_{4}^{+} / \mathrm{SO}_{4}^{2-}$ molar ratios were one or less compared to the eastern portion of the flight were the ratio was 2 or higher (Fig. 9). No general enhancements in WSOC concentrations are seen in the region of lower $\mathrm{NH}_{4}^{+} / \mathrm{SO}_{4}^{2-}$ molar ratios, consistent with (Zhang et al., 2004), who found no evidence for acid-catalyzed enhancements in organic aerosol during another study conducted in this region.

On the eastern leg of the flight an influence from urban emissions can be detected. For example, the slight oscillating pattern in WSOC concentration from about -74 to about -77 degrees longitude (Fig. 9) is due to entering and leaving the NYC plume. WSOC mass was about $20 \%$ to $30 \%$ higher in the area of NYC outflow compared to the surrounding regions. However, substantially larger increases in WSOC (200 to 500\%) relative to background were observed during the daytime downwind from NYC on other flights (Sullivan et al., 2006) compared to these nighttime data. Over the wide longitudinal range of this flight, the WSOC (and thus likely $\mathrm{OM}$ ) concentration was fairly uniform (standard deviation $=0.8 \mu \mathrm{gC} \mathrm{m}^{-3}$ ). Due to a decrease in sulfate concentration as sampling moved eastward, the WSOC fraction of fine particle mass increased from about $10 \%$ to $\sim 30 \%$ (Fig. 9) (OM mass fraction increased from $\sim 40 \%$ to $\sim 80 \%$ ). Overall, the distinct longitudinal distribution of higher sulfate and $\mathrm{PM}_{1.0}$ volume (mass) to the west, in contrast to more uniform WSOC and OM concentrations, clearly demonstrates the dominating influence of large $\mathrm{SO}_{2}$ sources on air quality over wide spatial regions (e.g. the western longitudes of this flight). WSOC and OM, on the other hand, appears to have fewer well-defined point sources during this flight, suggesting a more regional background from distant sources.

\section{Conclusions}

Airborne measurements in July and August 2004 of fine particle $\left(\mathrm{PM}_{1.0}\right)$ bulk chemical composition were made from the surface to $\sim 6 \mathrm{~km}$ altitude over northeastern United States and Canada, but with a focus on regions along the eastern seaboard. This paper summarizes the overall particle chemical climatology. The online measurements included ionic species chloride, nitrate, sulfate, sodium, ammonium, potassium, calcium and magnesium, and the water-soluble organic carbon (WSOC) fraction of the organic aerosol. In addition, measurements were made of particle volume and a suite of trace gases.

The bulk aerosol chemistry data were combined with fine particle volume data through a mass closure analysis to in- fer particle density and the ratio of organic matter (OM) to WSOC. The measured $\mathrm{PM}_{1.0}$ particle volume concentrations and inferred density were then used to estimate $\mathrm{PM}_{1.0}$ particle mass concentrations. Although the particle density varied with composition, the analysis predicted a fairly constant ratio of OM to WSOC of $3.1 \pm 1.6 \mu \mathrm{g} \mu \mathrm{gC}^{-1}$.

In this study, sulfate aerosol was ubiquitous with highest masses downwind of power generating regions (e.g., Ohio River Valley). Sulfate was also frequently observed in urban plumes. Sulfate concentrations were typically on the order of 2 to $4 \mu \mathrm{g} \mathrm{m}^{-3}$. Ammonium was often present and apparently associated with sulfate, with an ammonium to sulfate molar ratio near 2. However, in regions of high sulfate concentration, the calculated molar ratio was significantly less than 2 , typically near 1 . Nitrate was rarely present above the limit of detection $\left(0.04 \mu \mathrm{g} \mathrm{m}^{-3}\right)$, and was found to be mainly associated with biomass burning plumes originating from the Yukon/Alaska region of North America. Significant concentrations of ammonium were also observed in these biomass burning plumes. All other measured aerosol ionic species were generally below detection limits (typically $<0.2 \mu \mathrm{g} \mathrm{m}^{-3}$ for cation species; $0.04 \mu \mathrm{g} \mathrm{m}^{-3}$ for anion species). Sulfate and ammonium concentrations tended to be highest at lower altitudes, while the vertical distribution of nitrate had no discernable pattern.

WSOC, and hence inferred OM, was detected throughout the measurement domain, and was observed in highest concentrations (WSOC $>25 \mu \mathrm{gC} \mathrm{m}^{-3}$, inferred $\mathrm{OM}>75 \mu \mathrm{g} \mathrm{m}^{-3}$ ) within the Yukon/Alaskan biomass burning plumes. Apart from biomass burning plumes, WSOC was more spatially uniform than sulfate and highest concentrations appeared to be mainly associated with urban emissions and WSOC concentrations generally ranged in between 2 and $4 \mu \mathrm{gC} \mathrm{m}^{-3}$. Although, like sulfate, WSOC concentrations decreased rapidly with increasing altitude, the ratio of WSOC to sulfate increased sharply at about $2.5 \mathrm{~km}$ altitude, in the region of transition from the boundary layer to the free troposphere. Overall, in this study, sulfate comprised roughly $35 \%$ of the $\mathrm{PM}_{1.0}$ mass and $\mathrm{OM}$ roughly 55\%, however, the fractions varied depending on altitude, and the proximity to various sources, such as power generating facilities and urban regions.

Edited by: J. G. Murphy

\section{References}

Andreae, M. O. and Crutzen, P. J.: Atmospheric aerosols: biogeochemical sources and role in atmospheric chemistry, Science, 276(5315), 1052-1058, 1997.

Bae, M. S., Schauer, J. J., and Turner, J. R.: Estimation of the Monthly Average Ratios of Organic Mass to Organic Carbon for Fine Particulate Matter at an Urban Site, Aerosol Sci. Tech., 40, 1123-1139, 2006. 
Bates, T. S., Quinn, P. K., Coffman, D. J., Johnson, J. E., and Middlebrook, A. M.: Dominance of organic aerosols in the marine boundary layer over the Gulf of Maine during NEAQS 2002 and their role in aerosol light scattering, J. Geophys. Res., 110(D18), 1-14, doi:10.1029/2004JD004755, 2005.

Beattie, B. L. and Whelpdale, D. M.: Meteorological characteristics of large acidic deposition events at Kejimkujik, Nova Scotia, Water Air Soil Poll., 46(1-4), 45-59, 1989.

Brock, C. A., Hudson, P. K., Lovejoy, E. R., Sullivan, A., Nowak, J. B., Huey, L. G., Cooper, O. R., Cziczo, D. J., de Gouw, J., Fehsenfeld, F. C., Holloway, J. S., Hubler, G., Lafleur, B. G., Murphy, D. M., Neuman, J. A., Nicks, D. K., Orsini, D. A., Parrish, D. D., Ryerson, T. B., Tanner, D. J., Warneke, C., Weber, R. J., and Wilson, J. C.: Particle characteristics following cloud-modified transport from Asia to North America, J. Geophys. Res., 109(D23), 1-18, doi:10.1029/2003JD004198, 2004.

Brock, C. A., Schroder, F., Karcher, B., Petzold, A., Busen, R., and Fiebig, M.: Ultrafine particle size distributions measured in aircraft exhaust plumes, J. Geophys. Res., 105(D21), $26555-$ 26567, 2000.

Brock, C. A., Trainer, M., Ryerson, T. B., Neuman, J. A., Parrish, D. D., Holloway, J. S., Nicks, D. K., Jr., Frost, G. J., Hubler, G., Fehsenfeld, F. C., Wilson, J. C., Reeves, J. M., Lafleur, B. G., Hilbert, H., Atlas, E. L., Donnelly, S. G., Schauffler, S. M., Stroud, V. R., and Wiedinmyer, C.: Particle growth in urban and industrial plumes in Texas, J. Geophys. Res., 108(D3), 11-11, 2003

Brock, C. A., Washenfelder, R. A., Trainer, M., Ryerson, T. B., Wilson, J. C., Reeves, J. M., Huey, L. G., Holloway, J. S., Parrish, D. D., Hubler, G., and Fehsenfeld, F. C.: Particle growth in the plumes of coal-fired power plants, J. Geophys. Res., 107(D12), 9-1, 2002.

Brown, S. S., Ryerson, T. B., Wollny, A. G., Brock, C. A., Peltier, R., Sullivan, A. P., Weber, R. J., Dube, W. P., Trainer, M., Meagher, J. F., Fehsenfeld, F. C., and Ravishankara, A. R.: Variability in nocturnal nitrogen oxide processing and its role in regional air quality, Science, 311(5757), 67-70, 2006.

Chow, J. C., Watson, J. G., Fujita, E. M., Lu, Z., Lawson, D. R., and Ashbaugh, L. L.: Temporal and spatial variations of $\mathrm{PM}_{2.5}$ and $\mathrm{PM}_{10}$ aerosol in the Southern California Air Quality Study, Atmos. Environ.t, 28(12), 2061-2080, 1994.

de Gouw, J. A., Middlebrook, A. M., Warneke, C., Goldan, P. D., Kuster, W. C., Roberts, J. M., Fehsenfeld, F. C., Worsnop, D. R., Canagaratna, M. R., Pszenny, A. A. P., Keene, W. C., Marchewka, M., Bertman, S. B., and Bates, T. S.: Budget of organic carbon in a polluted atmosphere: Results from the New England Air Quality Study in 2002, J. Geophys. Res., 110(D16), D16305, doi:10.1029/2004JD005623, 2005.

de Gouw, J. A., Trainer, M., Fehsenfeld, F. C., Warneke, C., Parrish, D. D., and Holloway, J. S.: Emission sources and ocean uptake of acetonitrile $(\mathrm{CH} 3 \mathrm{CN})$ in the atmosphere, J. Geophys. Res.Atmos., 108(11), ACH 2-1-ACH 2-8, 2003.

de Gouw, J. A., Warneke, C., Stohl, A., Wollny, A. G., Brock, C. A., Cooper, O. R., Holloway, J. S., Trainer, M., Fehsenfeld, F. C., Atlas, E. L., Donnelly, S. G., Stroud, V.. and Lueb, A.: Volatile organic compounds composition of merged and aged forest fire plumes from Alaska and western Canada, J. Geophys. Res., 111(D10), D10303, doi:10.1029/2005JD006175, 2006.

Dockery, D. W., Pope III, C. A., Xu, X., Spengler, J. D., Ware, J. H.,
Fay, M. E., Ferris Jr., B. G., and Fe, S.: An association between air pollution and mortality in six U.S. cities, The New England Journal of Medicine, 329(24), 1753-1759, 1993.

Eatough, D. J., Wadsworth, A., Eatough, D. A., Crawford, J. W., Hansen, L. D., and Lewis, E. A.: Multiple-system, multichannel diffusion denuder sampler for the determination of fineparticulate organic material in the atmosphere, Atmos. Environ., Part A: General Topics, 27A(8), 1213-1219, 1993.

Fehsenfeld, F. C., Ancellet, G., Bates, T. S., Goldstein, A. H., Hardesty, R. M., Honrath, R., Law, K. S., Lewis, A. C., Leaitch, R., McKeen, S., Meagher, J., Parrish, D. D., Pszenny, A. P., Russell, P. B., Schlager, H., Seinfeld, J., Talbot, R., and Zbinden, R.: International Consortium for Atmospheric Research on Transport and Transformation (ICARTT): North America to EuropeOverview of the 2004 summer field study, J. Geophys. Res., 111(D23), D23S01, doi:10.1029/2006JD007829, 2006.

Fehsenfeld, F. C., Trainer, M., Parrish, D. D., Volz-Thomas, A., and Penkett, S.: North Atlantic Regional Experiment 1993 summer intensive, J. Geophys. Res., 101(D22), 28 869-28 875, 1996.

Heald, C. L., Jacob, D. J., Park, R. J., Alexander, B., Fairlie, T. D., Yantosca, R. M., and Chu, D. A.: Transpacific transport of Asian anthropogenic aerosols and its impact on surface air quality in the United States, J. Geophys. Res., 111(D14), D14310, doi:10.1029/2005JD006847, 2006.

Heald, C. L., Jacob, D. J., Park, R. J., Russell, L. M., Huebert, B. J., Seinfeld, J. H., Liao, H., and Weber, R. J.: A large organic aerosol source in the free troposphere missing from current models, Geophys. Res. Lett., 32(18), L18809, doi:10.1029/2005GL023831, 2005.

Heintzenberg, J.: Fine particles in global troposphere. A review, Tellus, Ser. B, 41B(2), 149-160, 1989.

Holloway, J. S., Jakoubek, R. O., Parrish, D. D., Gerbig, C., VolzThomas, A., Schmitgen, S., Fried, A., Wert, B., Henry, B., and Drummond, J. R.: Airborne intercomparison of vacuum ultraviolet fluorescence and tunable diode laser absorption measurements of tropospheric carbon monoxide, Jo. Geophys. Res., 105(D19), 24 251-24 261, 2000.

IPCC: Climate change 2007: The Physical Science Basis, Summary for Policymakers, IPCC Secretariat, Geneva, Switzerland, 2007.

Jaffe, D., Tamura, S., and Harris, J.: Seasonal cycle and composition of background fine particles along the west coast of the US, Atmos. Environ., 39(2), 297-306, 2005.

Jaffrezo, J. L., Aymoz, G., Delaval, C., and Cozic, J.: Seasonal variations of the water soluble organic carbon mass fraction of aerosol in two valleys of the French Alps, Atmos. Chem. Phys., 5, 2809-2821, 2005, http://www.atmos-chem-phys.net/5/2809/2005/.

Kelleher, T. J. and Feder, W. A.: Phytotoxic Concentrations Of Ozone On Nantucket Island: Long Range Transport From The Middle Atlantic States Over The Open Ocean Confirmed By Bioassay With Ozone-Sensitive Tobacco Plants, Environ. Poll., 17(3), 187-194, 1978.

Lee, Y. N., Weber, R., Ma, Y., Orsini, D., Maxwell-Meier, K., Blake, D., Meinardi, S., Sachse, G., Harward, C., Chen, T. Y., Thornton, D., Tu, F. H., and Bandy, A.: Airborne measurement of inorganic ionic components of fine aerosol particles using the particle-into-liquid sampler coupled to ion chromatography technique during ACE-Asia and TRACE-P, J. Geophys. Res., 108(D23), 14-11, 2003. 
Ma, Y., Weber, R. J., Lee, Y.-N., Orsini, D. A., Maxwell-Meier, K., Thornton, D. C., Bandy, A. R., Clarke, A. D., Blake, D. R., Sachse, G. W., Fuelberg, H. E., Kiley, C. M., Woo, J.-H., Streets, D. G., and Carmichael, G. R.: Characteristics and influence of biosmoke on the fine-particle ionic composition measured in Asian outflow during the Transport and Chemical Evolution Over the Pacific (TRACE-P) experiment, J. Geophys. Res., 108(D21), GTE 37-31-GTE 37-16, doi:10.1029/2002JD003128, 2003.

Maria, S. F., Russell, L. M., Turpin, B. J., Porcja, R. J., Campos, T. L., Weber, R. J., and Huebert, B. J.: Source signatures of carbon monoxide and organic functional groups in Asian Pacific Regional Aerosol Characterization Experiment (ACE-Asia) submicron aerosol types, J. Geophys. Res., 108(D23), ACE 5-1-ACE 5-14, doi:10.1029/2003JD003703, 2003.

Marple, V. A., Rubow, K. I., and Behm, S. M.: Microorifice uniform deposit impactor (MOUDI): description, calibration, and use, Aerosol Sci. Technol., 14(4), 434-446, 1991.

Mayol-Bracero, O. L., Gabriel, R., Andreae, M. O., Kirchstetter, T. W., Novakov, T., Ogren, J., Sheridan, P., and Streets, D. G.: Carbonaceous aerosols over the Indian Ocean during the Indian Ocean Experiment (INDOEX): chemical characterization, optical properties, and probable sources, J. Geophys. Res., 107(D19), 2-29, 2002.

Murphy, D. M., Thomson, D. S.. and Mahoney, M. J.: In situ measurements of organics, meteoritic material, mercury, and other elements in aerosols at 5 to 19 kilometers. Science, 282(5394), 1664-1669, 1998.

Nenes, A., Pandis, S. N., and Pilinis, C.: ISORROPIA: A new thermodynamic equilibrium model for multiphase multicomponent inorganic aerosols, Aquatic Geochem., 4(1), 123-152, 1998.

Novakov, T., Hegg, D. A., and Hobbs, P. V.: Airborne measurements of carbonaceous aerosols on the East Coast of the United States, J. Geophys. Res., 102(D25), 30 023-30 030, 1997.

Orsini, D. A., Ma, Y., Sullivan, A., Sierau, B., Baumann, K., and Weber, R. J.: Refinements to the particle-into-liquid sampler (PILS) for ground and airborne measurements of water soluble aerosol composition, Atmos. Environ., 37(9-10), 1243-1259, 2003.

Park, R. J., Jacob, D. J., Chin, M., and Martin, R. V.: Sources of carbonaceous aerosols over the United States and implications for natural visibility, J. Geophys. Res., 108(D12), AAC 5-1-AAC 5-14, doi:10.1029/2002JD003190, 2003.

Peltier, R. E., Sullivan, A. P., Weber, R. J., Wollny, A. G., Holloway, J. S., Brock, C. A., de Gouw, J. A., and Atlas, E. L.: No Evidence for Acid-Catalyzed Secondary Organic Aerosol Formation in Power-Plant Plumes over Metropolitan Atlanta, Georgia, Geophys. Res. Lett., 34(6), L06801, doi:10.1029/2006GL028780, 2007.

Pfister, G., Hess, P. G., Emmons, L. K., Lamarque, J. F., Wiedinmyer, C., Edwards, D. P., Petron, G., Gille, J. C., and Sachse, G. W.: Quantifying CO emissions from the 2004 Alaskan wildfires using MOPITT CO data, Geophys. Res. Lett., 32(11), L11809, doi:10.1029/2005GL022995, 2005.

Reiner, T., Sprung, D., Jost, C., Gabriel, R., Mayol-Bracero, L. O., Andreae, M. O., Campos, T. L., and Shetter, R. E.: Chemical characterization of pollution layers over the tropical Indian Ocean: Signatures of emissions from biomass and fossil fuel burning, J. Geophys. Res., 106(D22), 28 497-28 510, 2001.
Rogge, W. F., Mazurek, M. A., Hildemann, L. M., Cass, G. R., and Simoneit, B. R. T.: Quantification of urban organic aerosols at a molecular level: Identification, abundance and seasonal variation, Atmos. Environ., Part A: General Topics, 27A(8), 13091330, 1993.

Russell, P. B., Hobbs, P. V., and Stowe, L. L.: Aerosol properties and radiative effects in the United States east coast haze plume: an overview of the Tropospheric Aerosol Radiative Forcing Observational Experiment (TARFOX), J. Geophys. Res., 104(D2), 2213-2222, 1999.

Santarpia, J. L., Runjun, L., and Collins, D. R.: Direct measurement of the hydration state of ambient aerosol populations, J. Geophys. Res., 109(D18), 1-16, doi:10.1029/2004JD004653, 2004.

Stohl, A., Hittenberger, M., and Wotawa, G.: Validation of the Lagrangian particle dispersion model FLEXPART against largescale tracer experiment data, Atmos. Environ., 32(24), 42454264, 1998.

Sullivan, A. P., Peltier, R. E., Brock, C. A., de Gouw, J. A., Holloway, J. S., Warneke, C., Wollny, A. G., and Weber, R. J.: Airborne measurements of carbonaceous aerosol soluble in water over northeastern United States: Method development and an investigation into water-soluble organic carbon sources, J. Geophys. Res., 111(D23), 1-14, doi:10.1029/2005JD006485, 2006.

Sullivan, A. P., Weber, R. J., Clements, A. L., Turner, J. R., Bae, M. S., and Schauer, J. J.: A method for on-line measurement of water-soluble organic carbon in ambient aerosol particles: results from an urban site, Geophys. Res. Lett., 31(13), 4 pp., doi:10.1029/2004GL019681, 2004.

Tolocka, M. P., Solomon, P. A., Mitchell, W., Norris, G. A., Gemmill, D. B., Wiener, R. W., Vanderpool, R. W., Homolya, J. B., and Rice, J.: East versus West in the US: Chemical Characteristics of $\mathrm{PM}_{2.5}$ during the Winter of 1999, Aerosol Sci. Technol., 34(1), 88-96, 2001.

Turpin, B. J. and Lim, H. J.: Species contributions to PM2.5 mass concentrations: Revisiting common assumptions for estimating organic mass, Aerosol Sci. Technol., 35(1), 602-610, 2001.

Warneke, C., de Gouw, J. A., Stohl, A., Cooper, O. R., Goldan, P. D., Kuster, W. C., Holloway, J. S., Williams, E. J., Lerner, B. M., McKeen, S. A., Trainer, M., Fehsenfeld, F. C., Atlas, E. L., Donnelly, S. G., Stroud, V., Lueb, A., and Kato, S.: Biomass burning and anthropogenic sources of $\mathrm{CO}$ over New England in the summer 2004, J. Geophys. Res., 111(D23), 13, doi:10.1029/2005JD006878, 2006.

Weber, R. J., Orsini, D., Daun, Y., Lee, Y. N., Klotz, P. J., and Brechtel, F.: A particle-into-liquid collector for rapid measurement of aerosol bulk chemical composition, Aerosol Sci. Technol., 35(3), 718-727, 2001.

Weber, R. J., Sullivan, A. P., Peltier, R. E., Russell, A. G., Yan, B., Chen, Y., Zheng, M., De Gouw, J. A., Warneke, C., Brock, C. A., Holloway, J. S., Atlas, E. L., and Edgerton, E.: A Study of Secondary Organic Aerosol Formation in the Anthropogenic-Influenced Southeastern USA, J. Geophys. Res., doi:10.1029/2007JD008408, in press, 2007.

Wilson, J. C., Lafleur, B. G., Hilbert, H., Seebaugh, W. R., Fox, J., Gesler, D. W., Brock, C. A., Huebert, B. J., and Mullen, J.: Function and performance of a low turbulence inlet for sampling supermicron particles from aircraft platforms, Aerosol Sci. Technol., 38(8), 790-802, 2004.

Zappoli, S., Andracchio, A., Fuzzi, S., Facchini, M. C., Gelencser, 
A., Kiss, G., Krivacsy, Z., Molnar, A., Meszaros, E., Hansson, H. C., Rosman, K., and Zebuhr, Y.: Inorganic, organic and macromolecular components of fine aerosol in different areas of Europe in relation to their water solubility, Atmos. Environ., 33(17), 2733-2743, 1999.
Zhang, Q., Stanier, C. O., Canagaratna, M. R., Jayne, J. T., Worsnop, D. R., Pandis, S. N., and Jimenez, J. L.: Insights into the chemistry of new particle formation and growth events in Pittsburgh based on aerosol mass spectrometry, Environ. Sci. Technol., 38(18), 4797-4809, 2004. 